\author{
VIRA TRACZ \\ https://orcid.org/0000-0002-4589-3610 \\ Ukraiński Uniwersytet Katolicki we Lwowie
}

\title{
EPIDEMIA SZKARLATYNY WE LWOWIE W LATACH 1907-1910. URZĄD MIEJSKI, HIGIENIŚCI I POLITYKA ZDROWIA PUBLICZNEGO
}

\begin{abstract}
Abstrakt: Celem artykułu jest zbadanie, w jaki sposób odbyła się modernizacja w dziedzinie zdrowia publicznego we Lwowie w końcu XIX - na początku XX w. Analiza została przeprowadzona na przykładzie epidemii szkarlatyny w latach 1907-1910. Ma ona na celu wyjaśnienie mechanizmu funkcjonowania miejskiej służby zdrowia: w jaki sposób działania przeciwepidemiczne miały wpływ na życie mieszkańców, a także jak wyglądało zaangażowanie higienistów w realizację polityki miejskiej. Odpowiedzi na te pytania pozwolą częściowo scharakteryzować politykę zdrowia publicznego we Lwowie, a także zilustrować miejscowy ruch higieniczny.

Słowa kluczowe: Lwów, zdrowie publiczne, higieniści, rada miejska, epidemia szkarlatyny, modernizacja.
\end{abstract}

Abstract: The article aims to explore the process of modernisation of public health in Lviv from the late nineteenth to the early twentieth century, using the example of the scarlet fever epidemic of 1907-10. The author examines the functioning of the municipal health service, the impact of anti-epidemic measures on the lives of residents, and the involvement of hygienists in the implementation of municipal policy. The answers to these questions shed light on the public health policy in Lviv and the local hygiene movement.

Keywords: Lviv, public health, hygienists, city council, scarlet fever epidemic, modernisation.

\section{Wprowadzenie}

Na przełom XIX i XX w. przypada okres przemiany Lwowa w nowoczesną metropolię. Ważnym czynnikiem tego procesu było nadanie miastu w 1870 r. Statutu miejskiego, który przywrócił prawo do samorządu, to znaczy wybieralnej Rady Miejskiej oraz własnego budżetu. Od tego czasu 
Rada nie tylko zajmowała się wszystkimi sprawami gminy, lecz także kierowała polityką miejską i reagowała na kolejne wyzwania, które przynosił rozrost miasta i potrzeba jego modernizacji. W ostatnich trzech dekadach XIX w. proces urbanizacji nabrał przyspieszenia. Jeśli w 1869 r. we Lwowie było 87109 mieszkańców, a w 1890 - 127 943, to już w 1900 r. prawie 160 tys., i wreszcie w 1910 r. $-206113^{2}$.

Wzrost miasta wymagał rozbudowy infrastruktury oraz służb miejskich. Oprócz obiektywnie istniejących potrzeb dużo zmian było podyktowanych przez nowe spojrzenie na zdrowie publiczne. Rozwój w tej dziedzinie stał się ważnym czynnikiem przemian modernizacyjnych: wiek XIX nie bez powodu nazywany jest „wiekiem higieny”. Nowe rozumienie zdrowia zbiorowości, które kształtowało się w ciągu tego stulecia, umieściło higienę na czołowym miejscu spośród wszystkich dziedzin życia społecznego. Higiena publiczna była jednym z najważniejszych czynników rozwoju ówczesnych miast oraz kształtowania sposobu rozumienia, jakie powinno być miasto nowoczesne. Nowa dyscyplina miała na celu zapobieganie wszystkim zagrożeniom życia oraz zdrowia ludności. Początkowo koncepcja zdrowia publicznego rozwijała się pod wpływem postulatów oświecenia dotyczących postępu i cywilizacji, zdrowia jako przyrodzonego stanu ludzkości i jako prawa każdego człowieka, a wreszcie potrzeby kontroli społecznej. Zdrowie obywateli rozumiano jako gwarancję rozwoju państwa. Zmiany w tej sferze przyspieszały postęp demograficzny, rozwój miast oraz industrializacja. W tych nowych warunkach epidemie chorób zakaźnych występowały częściej oraz rozprzestrzeniały się szybciej niż w dawnych czasach. Szczególne znaczenie miały epidemie cholery, które pojawiły się w Europie w latach trzydziestych. Jednocześnie postępował rozwój nauk medycznych, statystyki medycznej, epidemiologii, a w połowie XIX w. także bakteriologii, które powodowały stopniowe zanikanie teorii miazmatycznej.

Ważną rolę w administracji, samorządzie, nauce, edukacji i innych aspektach życia społecznego zaczęli odgrywać fachowcy w dziedzinie zdrowia publicznego - higieniści. Ich działalność zawodowa i edukacyjna nie ograniczała się jedynie do wysiłków pojedynczych osób, a doprowadziła do powstania ruchu higienicznego. Narodził się on na początku XIX w. we Francji, a następnie pojawił się w Wielkiej Brytanii, gdzie w 1848 r. został przyjęty akt o zdrowiu publicznym (Public Health Act),

${ }^{1}$ Wiadomości statystyczne o mieście Lwowie, Lwów 1874, s. 1; ibidem, Lwów 1895, s. 1.

2 Wiadomości statystyczne o mieście Lwowie, Lwów 1910, s. 16; ibidem, Lwów 1914, s. 9.

${ }^{3}$ M. Demel, Pedagogiczne aspekty warszawskiego ruchu higienicznego (1864-1914), Kraków 1964 (Monografie Pedagogiczne, t. 12), s. 16. 
i w kolejnych państwach europejskich. Postępy na polu higieny od lat pięćdziesiątych stopniowo wchodziły do programów wystaw światowych i krajowych. Kwestia zdrowia publicznego stała się przedmiotem obrad sanitarnych kongresów międzynarodowych. W drugiej połowie XIX w. stworzenie zdrowego środowiska do życia, wskaźniki demograficzne oraz skuteczność w walce z epidemiami chorób zakaźnych weszły do listy kryteriów oceny poziomu rozwoju zarówno małych miasteczek, jak i całego państwa. Głównym obszarem, na którym wprowadzano nowe praktyki w zakresie zdrowia publicznego, były miasta ${ }^{4}$.

Owe praktyki kształtowały zarówno życie codzienne lwowian, jak i zmieniały przestrzeń stołecznego miasta w końcu XIX i na początku XX w. Znaczenia nabrały takie pojęcia i praktyki jak wypoczynek na świeżym powietrzu, ćwiczenia gimnastyczne, „higieniczne” kapelusze i suknie, higieniczne warunki pracy i życia, badania, czy uczniowie używają chusteczek do nosa i jak często zażywają kąpieli, jaki jest higieniczny stan piekarń lwowskich i „stosunki higieniczne” w mieście w ogóle ${ }^{5}$. Zmiany światopoglądowe, wymogi ustawodawcze, stały wzrost liczby mieszkańców oraz epidemie zmuszały urząd miejski we Lwowie do wzmożonej troski o zdrowie publiczne i zorganizowanie miejskiej służby zdrowia. Jedną z najważniejszych innowacji „higienicznych” było otwarcie w roku 1901 scentralizowanego wodociągu oraz nowej rzeźni miejskiej. W trakcie rozbudowy sieci kanalizacyjnej stopniowo znikały pod ziemią koryta rzek Pełtwi i Pasieki oraz liczne strumienie i potoki. Dla utrzymania czystości ulic na początku XX w. założono służbę oczyszczania miasta, która zajmowała się wywozem śmieci oraz sprzątaniem ulic. Aby to ułatwić, a także dla czystości powietrza miejskiego, ulic i ułatwienia komunikacji ulice miejskie brukowano. Ze względu na znaczny ruch budowlany - nie tylko budowy nowych, lecz także przebudowy istniejących domów istotna stała się kwestia uregulowania przepisów w tym zakresie.

Działalność w dziedzinie zdrowia publicznego była przedmiotem dumy urzędu miejskiego. Chyba najczęściej, oprócz wodociągu miejskiego, chwalono się istnieniem własnej służby zdrowia oraz wysiłkami w walce z epidemiami chorób zakaźnych. Jednak polityka zdrowia publicznego we Lwowie była zarazem przedmiotem krytyki - zarówno samych mieszkańców, jak

${ }^{4}$ G. Rosen, A History of Public Health, Baltimore 2015; A.F. La Berge, Mission and Method. The Early Nineteenth-Century French Public Health Movement, Cambridge, New York 1992; W.F. Willcox, Statistics at International Congresses on Hygiene and Demography, „Publications of the American Statistical Association" 13, 1912, 98, s. 182-185; M. Hietala, Services and Urbanization at the Turn of the Century. The Diffusion of Innovations, Helsinki 1983.

${ }^{5}$ O niektórych praktykach zob. О. Середа, Щоденне життя, w: Історія Львова, t. 2: 1772-1918, red. Я. Ісаєвич, М. Литвин, Ф. Стеблій, Львів 2007, s. 318-333. 
i nierzadko przedstawicieli urzędów różnych szczebli. Uwagi krytyczne stale dobiegały ze środowiska higienistów. Warto zaznaczyć, że owa wspólnota zawodowa higienistów we Lwowie nie była jednolita. Tutaj, podobnie jak i w innych dziedzinach życia społecznego w Galicji Wschodniej, coraz częściej i ostrzej zaznaczał się podział narodowy, zwłaszcza na „polskie” i „ukraińskie”. Wzrost napięcia w stosunkach politycznych i społecznych na początku XX w. stawał się coraz bardziej odczuwalny także i w środowiskach ekspertów. Mimo tego wciąż zachowało się doświadczenie współpracy zawodowej. Formowanie się środowiska higienistów było związane ze zjazdami lekarzy oraz przyrodników polskich. Stały się one impulsem do założenia we Lwowie Towarzystwa Higienicznego.

W celu popularyzacji wiedzy „higienicznej” Towarzystwo na początku XX w. wydawało podejmujące tę tematykę czasopisma i okresowo prowadziło wykłady publiczne. Część wystawy przyrodniczo-lekarskiej w 1907 r., w której organizację zostali zaangażowani higieniści lwowscy, była poświęcona zdrowiu publicznemu. Dwa lata później kwestię higieny omawiano na kongresie Proswity. W lecie 1914 r. we Lwowie odbył się I Zjazd Higienistów Polskich. Jako popularyzator higieny występowało także założone niedługo przed początkiem wojny Ukraińskie Towarzystwo Lekarskie ${ }^{6}$. Większość higienistów lwowskich była lekarzami.

${ }^{6}$ Z. Jastrzębowski, Spory o model lecznictwa. Opieka zdrowotna w koncepcjach polskiej polityki społecznej w XIX i XX wieku (do 1948 roku), Łódź 1994, s. 37-50; A. Łupienko, Urban Knowledge Transfer Between the Cities of Warsaw, Krakow, Lviv and Poznan at the Turn of the Nineteenth and Twentieth Centuries, „Zeitschrift für Ostmitteleuropa-Forschung” 67, 2018, 4, s. 578-600. W owej publikacji Aleksander Łupienko dopuścił się pewnych nieścisłości - czasopismo lwowskie „Przegląd Higieniczny” zaczęło ukazywać się w 1902, a nie w 1900 r. (s. 582-583). Także I Zjazd Higienistów Polskich we Lwowie został przeniesiony i odbył się w 1914 r. (s. 596). В. Трач, Гігієнічні часописи та формування дискурсу громадського здоров'я у Львові на початку ХХ століття, „Місто. Історія, культура, суспільство” 2017, 2, s. 136-161; еadem, „Для культури в напрямку гігієни”. Громадсъке здоров'я та „виставковий комплекс” у Львові наприкінизі XIX - на початку XX cm., „Місто. Історія, культура, суспільство” 2019, 1, s. 99-118; eadem, „Живемо під знаком гігієни". Професійні з'ізди другоі половини XIX - початку XX cm. та розвиток гігієнічного руху в Галичині, „Дослідження з історії і філософії науки і техніки” 2019, 2, s. 20-41; eadem, „Гігієна є мірилом культури”. Українські фахові кола та гігієнічний рух у Львові на початку XX cm., „Україна. Культурна спадщина, національна свідомість, державність” 2019, 32, s. 22-44. Zob. także A. Łupienko, Some Remarks on the Birth of Modern City Planning in the Polish Territories (1850-1914). The Impact of the Hygienic Movement, „Mesto a dejiny” 5, 2016, 2, s. 18-34; idem, Wkład ruchu higienicznego w polska myśl urbanistyczna (1850-1914), w: Architektura w mieście, architektura dla miasta. Społeczne aspekty funkcjonowania architektury na ziemiach polskich lat 1815-1914, red. M. Getka-Kenig, A. Łupienko, Warszawa 2017, s. 57-70; E. Dolata, Rozwój ruchu higienicznego w Galicji w okresie autonomicznym ze szczególnym uwzględnieniem higieny szkolnej, Rzeszów 2016 (Galicja i jej dziedzictwo, t. 23). 
Niektórzy z nich pracowali w krajowej lub miejskiej służbie zdrowia, a także brali udział w miejscowym życiu politycznym i wybierano ich do składu lwowskiej Rady Miejskiej. Zajmując stanowiska polityczne, uczestniczyli w formowaniu polityki zdrowia publicznego na różnych poziomach. Uzyskanie mandatu radnego było jednym ze sposobów komunikacji między ruchem higienicznym a polityką zdrowia publicznego w mieście w końcu XIX - początku XX w. Zdaniem Heidi Hein-Kircher, kwestia zdrowia publicznego była jednym z najważniejszych problemów dla autonomicznego rządu miejskiego. Z jednej strony, związana była z procesem urbanizacji, z drugiej - z dyskursem nacjonalistycznym, podporządkowanym koncepcji tworzenia nowoczesnego "miasta polskiego"7.

Historiografia Lwowa i tego okresu jest, rzecz jasna, bardzo bogata. Proces przemiany Lwowa $\mathrm{w}$ miasto nowoczesne historycy rozpatrywali przez pryzmat badań różnych jego elementów, zwłaszcza instytucji urzędu miejskiego ${ }^{8}$, zmian demograficznych ${ }^{9}$, rozwoju ekonomicznego ${ }^{10}$, zmian przestrzennych oraz rozwoju architektury ${ }^{11}$, symbolicznego oznaczenia przestrzeni miejskiej ${ }^{12}$ itd. Natomiast kwestii polityki zdrowia publicznego w mieście poświęcano stosunkowo niewiele uwagi. Najlepiej zbadano kwestię budowy wodociągu i kanalizacji ${ }^{13}$. Modernizacje

7 H. Hein-Kircher, Best Practices From a Polish Perspective. Improving Health Conditions in Lviv Around 1900, w: Interurban Knowledge Exchange in Southern and Eastern Europe, 1870-1950, red. E. Gantner, H. Hein-Kircher, O. Hochadel, New York 2021, s. 134-152.

${ }^{8}$ В. Кіселичник, Міське право та самоврядування громади Львова (друга половина XIX - початок XX cm.), Львів 2008; Ł.T. Sroka, Rada miejska we Lwowie w okresie autonomii galicyjskiej 1870-1914. Studium o elicie władzy, Kraków 2012.

9 Zob. np. K. Wnęk, L.A. Zyblikiewicz, E. Callahan, Ludność nowoczesnego Lwowa w latach 1857-1938, Kraków 2006; K. Wnęk, Przemiany demograficzne we Lwowie w latach 1829-1938, „Zeszyty naukowe UJ. Prace Historyczne” 135, 2008, s. 113-127; idem, Nierówność społeczna wobec śmierci we Lwowie w końcu XIX i na początku XX wieku, w: Choroba i śmierć w perspektywie społecznej w XIII-XXI wieku, red. D.K. Chojecki, E. Włodarczyk, Warszawa 2010, s. 221-250.

10 Zob. np. S. Hoszowski, Ekonomiczny rozwój Lwowa w latach 1772-1914, Lwów 1935; idem, Ceny we Lwowie w latach 1701-1914, Lwów 1934.

${ }^{11}$ Zob. np. J. Lewicki, Między tradycją a nowoczesnościa. Architektura Lwowa lat 1893-1918, Warszawa 2005; М. Долинська, Українські квартали в часі австрійського періоду Львова, „Вісник Державного університету «Львівська політехніка»” 1999, 379, s. 199-204; Architektura Lwowa XIX wieku, red. J. Purchla, Kraków 1997; I. Жук, Львів Левинського. Місто і будівничий, Київ 2010.

${ }_{12}$ M. Prokopovych, Habsburg Lemberg. Architecture, Public Space, and Politics in the Galician Capital, 1772-1914, West Lafayette 2008; H. Binder, Making and Defending a Polish Town. „Lwów” (Lemberg), 1848-1914, „Austrian History Yearbook” 2003, 34, s. 57-81.

13 П. Гранкін, Каналізациія міста Львова (від початку XV cm. до 1939 р.), Львів 2015; Х. Харчук, Водогін міста Львова, (від початку XV cm. до 1939 р.), Львів 2015; А. Łupienko, 
gospodarki miejskiej przeanalizował Aleksander Łupienko przez pryzmat roli techników lwowskich w tym procesie ${ }^{14}$. Niektóre aspekty związane $\mathrm{z}$ uporządkowaniem dzielnic oraz mieszkań były obecne w badaniach historyków architektury i rozpatrywane w kontekście zmian przestrzennych ${ }^{15}$. Krótki szkic o polityce ochrony zdrowia zawiera praca Tomasza Łukasza Sroki ${ }^{16}$, a także Wasyla Kisełycznyka ${ }^{17}$. Badanie Włodzimierza Bernera ukazuje ogólny ogląd sytuacji epidemicznej w mieście na podstawie materiałów statystycznych ${ }^{18}$. W tym artykule chcemy dokładniej przyjrzeć się, jak odbywała się modernizacja w dziedzinie zdrowia publicznego we Lwowie na przykładzie epidemii szkarlatyny w latach 1907-1910.

Epidemie chorób zakaźnych były testem na skuteczność pracy służby zdrowia i wystawiały świadectwo politykom zajmującym się zdrowiem publicznym. Oprócz dobrze znanej wszystkim cholery, mieszkańców niepokoiły i inne epidemiczne choroby zakaźne. W badanym okresie ustawodawstwo zwykle zaliczało do nich: ospę prawdziwą, odrę, szkarlatynę (płonicę), dyfteryt, krztusiec, dur brzuszny, dur plamisty oraz dyzenterię (czerwonkę). We Lwowie najwyższy wskaźnik śmiertelności wskutek tychże chorób na przestrzeni prawie 40 lat (1873-1913) wynosił 20,4 proc. ogółu zmarłych w ciągu jednego roku (wykres 1 ). Widoczny był stopniowy spadek umieralności na tę grupę chorób - od lat 1899-1900 była ona przyczyną przyczyną 5 (a nawet mniej) proc. zgonów. W latach 1908, 1909 i 1912 obserwowano wzrost śmiertelności spowodowany epidemiami płonicy. Ogólny spadek umieralności z powodu chorób zakaźnych od końca lat 1890 był widoczny także w Krakowie ${ }^{19}$.

Rivers, Public Hygiene and Urban Feelings. The Case of the Pettew River in Lviv before 1914, „Biuletyn Polskiej Misji Historycznej” 14, 2019, s. 363-382.

14 A. Eupienko, Transnational Modernization of the Periphery? The Role of Engineers in the Rise of Modern Lviv (1870-1914), „Yearbook of Transnational History” 3, 2020, s. 55-74.

15 Zob. także A. Zayarnyuk, Lviv's Uncertain Destination. A City and Its Train Terminal from Franz Joseph I to Brezhnev, Toronto-Buffalo 2020; J.M. Małecki, ,Mieszkaja w prawdziwym raju" (Możliwości badania jakości życia w Krakowie i we Lwowie w okresie autonomii galicyjskiej), „Annales Universitatis Paedagogicae Cracoviensis. Studia ad Bibliothecarum Scientiam Pertinentia" 9, 2011, s. 157-164.

${ }^{16}$ Ł.T. Sroka, op. cit., s. 117-190, o polityce zdrowotnej s. 177-186.

17 В. Кіселичник, op. cit., s. 204-212.

${ }^{18}$ W. Berner, Stan sanitarny, ochrona zdrowia i sytuacja epidemiologiczna chorób zakaźnych we Lwowie w okresie autonomii Galicyjskiej (lata 60./70. XIX w. - do 1914 r.), „Przegląd Epidemiologiczny" 61, 2007, 4, s. 815-825.

19 B. Ogórek, Niezatarte piętno? Wpływ I wojny światowej na ludność Krakowa, Kraków 2018, s. 113. 
Wykres 1 . Odsetek zmarłych na epidemiczne choroby zakaźne wobec ogółu zgonów we Lwowie w latach 1873-1913 (ospa prawdziwa, odra, szkarlatyna, dyfteryt, krztusiec, dur brzuszny, dur plamisty, dyzenteria [czerwonka])

25

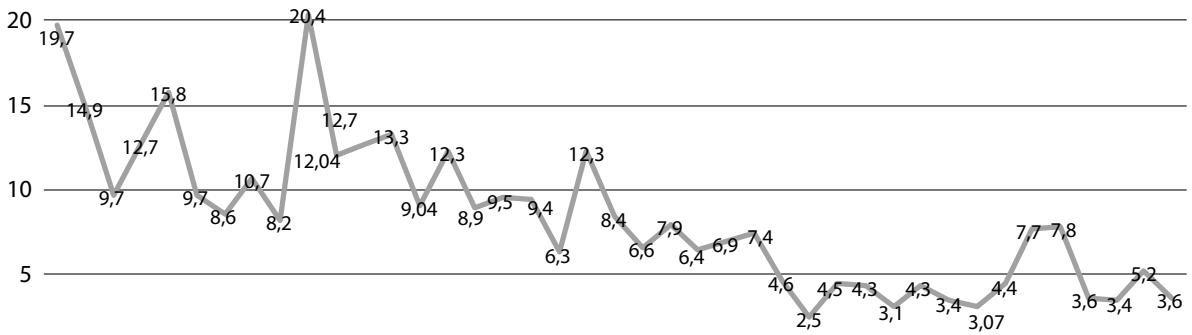

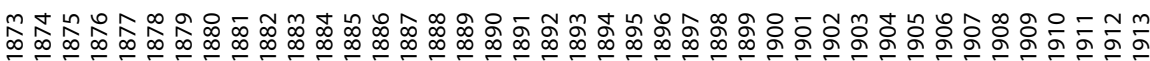

Źródło: obliczenia własne na podstawie Wiadomości statystyczne o mieście Lwowie, Lwów 1874, 1876, 1877, 1892, 1893, 1895, 1897, 1905, 1907, 1910, 1911, 1914, 1926; A. Pawlikowski, O stosunkach zdrowotnych w mieście Lwowie, t. 1, Lwów 1891, t. 2, Lwów 1894; W. Legeżyński, Stosunki zdrowotne w mieście Lwowie w roku 1905 i 1906, Lwów 1907.

Epidemie cholery występowały coraz rzadziej. We Lwowie w XIX w. ostatnia miała miejsce w 1894 r. (następne - podczas I wojny światowej). Zmniejszyła się liczba epidemii duru brzusznego i dyzenterii, co prawdopodobnie było związane $\mathrm{z}$ wybudowaniem wodociągu oraz stopniowym kanalizowaniem miasta. Podczas gdy w 1900 r. na dur brzuszny chorowało 406 osób, w kolejnych latach poziom zachorowań nie przekraczał 300 chorych, a średni wskaźnik zachorowalności do roku 1913 wynosił 187 osób. Wysoki wskaźnik zachorowalności na dyzenterię przypadł na rok 1890 - 796 osób, 1892 r. - 429, a w roku 1897 - 134 chorych. W następnych latach rzadko przewyższał 25-30 osób, z wyjątkiem lat 1912-1913, kiedy zachorowało 93 i 92 mieszkańców.

Natomiast wciąż okresowo występowały epidemie błonicy i chorób zakaźnych wieku dziecięcego - odry, krztuśca oraz szkarlatyny. Do połowy lat dziewięćdziesiątych znaczny odsetek zgonów z powodu wspomnianych wyżej epidemicznych chorób zakaźnych przypadał na ospę prawdziwą, ale stopniowo spadł do pojedynczych wypadków wskutek wprowadzenia szczepień ochronnych. Na odrę i krztusiec przypadało nie więcej niż 21 proc., na dyfteryt - około 25 proc. zgonów. Natomiast szkarlatyna występowała dość powszechnie i w niektórych latach z jej powodu umierało około 30-50 proc. wszystkich zmarłych na epidemiczne choroby zakaźne, w roku 1908 było to 71,5 proc. czyli 239 osób z 334 . W latach 1897-1913 każdego roku na dyfteryt chorowało przeciętnie 
257 osób. Większe nasilenie choroby mało miejsce w latach 1904-1906, gdy chorowało odpowiednio 486, 356 i 371 osób. Wysoki stopień wahania zachorowalności miała odra. Przykładowo, w 1900 r. zachorowało 79 osób, a w następnym - 669. Średnio w latach 1897-1913 chorowało rocznie na odrę 490 osób. Epidemicznie choroba występowała w roku 1904 - 1621 chorych, 1909 r. - 1977 chorych oraz w 1912 r. - 946. Jednak umieralność była niska. W 1904 r. zmarło 21 osób, a w 1909 r. $61^{20}$. W sumie spośród chorób zakaźnych najwięcej ofiar pochłaniała gruźlica płuc.

Interesująca nas epidemia szkarlatyny trwała od jesieni 1907 r. do wiosny 1910 r. i była największą w badanym okresie. Szczyt zachorowalności przypadł na lato-jesień 1908 r. W związku z tym, latem 1908 r. wokół epidemii powstała w miejskiej prasie dyskusja, która daje powody, by mówić o wpływie wyborów do Lwowskiej Rady Miejskiej i Sejmu Galicyjskiego w pierwszej połowie 1908 r. na szczegóły walki ze szkarlatyną w tym roku. Analizując przypadek tej epidemii, mamy na celu ukazanie mechanizmu funkcjonowania miejskiej służby zdrowia, zbadanie, w jaki sposób działania przeciwepidemiczne oddziaływały na życie mieszkańców, a także jaki wpływ miało zaangażowanie higienistów w realizację polityki miejskiej. Odpowiedzi na te pytania pozwolą częściowo scharakteryzować politykę zdrowia publicznego we Lwowie, jak również więcej powiedzieć o miejscowym ruchu higienicznym.

Epidemia trwała ponad dwa lata, lecz główne działania przeciwepidemiczne zostały wypracowane latem-jesienią 1908 r. i były dalej korygowane w zależności od sytuacji. Zatem, żeby odpowiedzieć na zadane pytania, skupimy naszą uwagę tylko na początkowym etapie epidemii.

Za główne źródła danych statystycznych posłużyły publikowane sprawozdania miejskiego oraz krajowego biura statystycznego, a także sprawozdania lwowskich fizyków miejskich. Należy zaznaczyć, że nie zawsze dane i kategorie analizy pokrywają się w obu tych źródłach. Dlatego obliczenia dają nam możliwość mówienia o tendencji, a nie o dokładnych liczbach. Dla analizy przebiegu epidemii szczególnie ważne jest sprawozdanie komisji, opublikowane w lecie 1909 r. Z kolei dla analizy działań urzędu miasta głównym źródłem są wybrane dzienniki oraz branżowe czasopisma lekarskie, a także organ prasowy Rady Miejskiej oraz niektóre materiały archiwalne.

${ }^{20}$ Obliczenia własne na podstawie Wiadomości statystyczne o mieście Lwowie, Lwów 1874, 1876, 1877, 1892 , 1893, 1895, 1897, 1905, 1907, 1910, 1911, 1914, 1926; A. Pawlikowski, 0 stosunkach zdrowotnych w mieście Lwowie, t. 1, Lwów 1891, t. 2, Lwów 1894; W. Legeżyński, Stosunki zdrowotne w mieście Lwowie w roku 1905 i 1906, Lwów 1907. 


\section{Miejska służba zdrowia i zwalczanie chorób zakaźnych w świetle przepisów prawnych}

Obowiązek dbania o ochronę zdrowia mieszkańców nakładały na organy samorządu miejskiego Ustawa gminna z 1866 r. oraz Ustawa o organizacji publicznej służby zdrowia, przyjęta w kwietniu $1870 \mathrm{r} .{ }^{21}$ Miejską służbę zdrowia, inaczej zwaną fizykatem miejskim, we Lwowie zorganizowano w roku 1872. Składała się z fizyka miejskiego (lekarza naczelnego) oraz siedmiu lekarzy miejskich - jednego na każdy z siedmiu okręgów sanitarnych, na które podzielone było miasto. Podziały sanitarny i administracyjny nie pokrywały się. W tym czasie miasto miało pięć dzielnic administracyjnych: I (przedmieście Halickie), II (Krakowskie albo Gródeckie), III (Żółkiewskie), IV (Łyczakowskie), które od różnych stron przylegały do Śródmieścia (V). Okręgi sanitarne miały inaczej wytyczone granice: pierwsza dzielnica sanitarna obejmowała istotną część przedmieścia Żółkiewskiego; druga - Łyczakowskie oraz część Żółkiewskiego; trzecia i czwarta - przedmieście Halickie. Krakowskie dzieliło się wzdłuż ulicy Gródeckiej na piątą i szóstą dzielnicę sanitarną. Śródmieście stanowiło siódmy okręg sanitarny. Oprócz lekarzy, fizyk miejski sprawował także nadzór nad dezynfektorami miejskimi i funkcjonariuszami sanitarnymi ${ }^{22}$.

${ }^{21}$ Ustawa z dnia 30 kwietnia 1870, względem organizacji publicznej służby zdrowia, „Dziennik Ustaw Państwa dla Królestw i Krajów w Radzie Państwa Reprezentowanych” 1870, 25, s. 125-130. Charakterystyka ogólna służby zdrowia w Galicji, zob. S. Rejman, Organizacja państwowej i gminnej służby zdrowia w Galicji w okresie autonomicznym w świetle przepisów prawnych, w: Urzędy państwowe, organy samorządowe i kościelne oraz ich kancelarie na polsko-ruskim pograniczu kulturowym i etnicznym $w$ okresie od XV do XIX wieku, red. H. Gmiterek, J. Łosowski, Kraków 2010, s. 405-435; P. Franaszek, Zdrowie publiczne w Galicji $w$ dobie autonomii (wybrane problemy), Kraków 2002, s. 11-23. O systemie szpitalnym oraz niektóre dane statystyczne o wydatkach na krajowy system ochrony zdrowia itp. zob. P. Franaszek, Informator statystyczny do dziejów społeczno-gospodarczych Galicji. Zdrowie publiczne w Galicji w dobie autonomii, red. H. Madurowicz-Urbańska, Kraków 2001 (Informatory Statystyczne do Dziejów Społeczno-Gospodarczych Galicji, t. 15).

${ }^{22}$ I dzielnica sanitarna - tzw. Żółkiewskie i Zamarstynowskie; II - tzw. Łyczakowskie i Piekarskie; III - tzw. Halickie albo Zielone, Stryjskie; IV - tzw. Chorąszczyzna i Wulka; V - tzw. Nowy Świat i Bajki albo dzielnica Krakowska na lewo od Gródeckiej; VI - tzw. Bogdanówka, Kleparowskie albo dzielnica Krakowska na prawo od Gródeckiej; VII - tzw. Śródmieście, Nadpełtwie. Części Żółkiewskiego były rozmieszczone w VI i VII okręgach sanitarnych. Przybliżony schemat rozmieszczenia dzielnic sanitarnych wobec administracyjnych został ułożony przez autora na podstawie opisu granic dzielnic sanitarnych fizyka miejskiego, W. Legeżyński, Stosunki zdrowotne, s. 337-338. Nazwy okręgów sanitarnych nie były ustalone jako nazwy dzielnic administracyjnych. Kilka użytych nazw dodatkowych podano według artykułu Kronika Lwowska. Szkarlatyna, „Gazeta Narodowa" 1908, 200, s. 2. 
Do Rady Miejskiej należały główne zadania w określeniu polityki zdrowia publicznego w gminie miasta Lwowa, a do Magistratu - decyzje wykonawcze, a także realizacja praktyczna uchwał Rady. W Radzie opracowanie różnych spraw rozdzielano między sekcje i komisje, w Magistracie - między departamenty ${ }^{23}$. W latach dziewięćdziesiątych jako organ doradczy została także powołana Komisja Zdrowotna Miasta Lwowa (często nazywana Radą Zdrowia). Była to swego rodzaju rada ekspercka w dziedzinie zdrowia publicznego w mieście i swoje wnioski wysyłała do rozpatrzenia do Rady Miejskiej oraz do Magistratu. Odpowiednie departamenty oraz inne jednostki administracyjne, a zwłaszcza Krajowa Rada Zdrowia, pracowały w ramach Namiestnictwa Galicyjskiego i Wydziału Krajowego, z którymi miasto współpracowało w ten lub inny sposób.

Środki do walki z chorobami zakaźnymi w imperium Austro-Węgierskim określano poprzez liczne ogólnopaństwowe akty ustawodawcze oraz rozporządzenia ministerialne, które były podstawą do decyzji lokalnych władz w prowincjach. Odrębna Ustawa o zapobieganiu chorobom zakaźnym została przyjęta w kwietniu $1913 \mathrm{r}^{24}$

Ustawa z 1870 r. nakładała na gminę obowiązek zabezpieczenia „środków miejscowych" w celu zapobiegania chorobom zakaźnym oraz ich rozpowszechniania się (\$ 4a). Oprócz szczepienia przeciwko ospie prawdziwej głównym działaniem prewencyjnym przewidzianym przez prawo, była „asanacja” - utrzymanie czystości i należytego stanu sanitarnego w miejscowościach i poza nimi, wodociągach, studniach oraz zbiornikach wodnych. Według ustawy obowiązek realizacji tych wymogów należał do „własnego” zakresu działalności gminy, czyli był realizowany „własnymi siłami" oraz funduszami $(\S 3)^{25}$.

Aby zapewnić kontrolę nad rozpowszechnianiem się chorób zakaźnych wyznaczone osoby oraz instytucje (organy zwierzchności gminy, lekarze, wojskowi itd.) były zobowiązane zawiadomić odpowiednie organy „władzy politycznej” o przypadkach choroby. Jeżeli lekarz powiatowy

${ }^{23}$ Dokładniej o kompetencjach urzędów miejskich, В. Трач, Органи „громадської служби здоров'я" в структурі Львівського магістрату наприкіниі XIX - на початку XX cm., „Проблеми історії України XIX - поч. XX ст.” 28, 2018, s. 125-140.

${ }^{24}$ Ustawa z dnia 14 kwietnia 1913, dotyczaca zapobiegania chorobom zaraźliwym oraz ich zwalczania, „Dziennik Ustaw Państwa dla Królestw i Krajów w Radzie Państwa Reprezentowanych" 1913, 32, s. 221-230. Zob. także R. Tomczyk, Zagrożenia epidemiologiczne na terenie austriackiej części monarchii habsburskiej w XIX w. (do 1914 r.). Aspekty prawne i administracyjne, „Galicja. Studia i Materiały” 2015, 1, s. 99-113; P. Franaszek, Publiczna ochrona zdrowia w Galicji w dobie autonomii, w: Przełom nowożytny w nauce europejskiej i jego kontekst społeczno-kulturowy, red. B. Płonka-Syroka, A. Syroka, Wrocław 2004 (Studia z Dziejów Kultury Medycznej, t. 8), s. 133-157.

${ }^{25}$ Ustawa z dnia 30 kwietnia 1870, s. 125-132. 
potwierdzał, że choroba nabiera charakteru epidemii, do takiej gminy na koszt państwa kierowano lekarza w celu leczenia chorych i nadzoru nad wykonaniem przepisów sanitarno-policyjnych. Gmina wedle możliwości powinna była zapewnić zakażonym oddzielne pomieszczenie na czas leczenia. Szpitale powszechne miały obowiązek przyjmowania takich osób. Obowiązkowym środkiem prewencyjnym była dezynfekcja ${ }^{26}$.

Pojęcie „epidemia” było regulowane przez prawo. W Galicji, według reskryptu Namiestnictwa z 1856 r., podstawą dla stwierdzenia istnienia epidemii w danej gminie był fakt istnienia powyżej pięciu przypadków tej samej choroby zakaźnej albo dwa przypadki w jednym domu jednocześnie ${ }^{27}$. Oczywiście, ta norma nie była odpowiednia dla większych miejscowości, w tym dla Lwowa. Dlatego też na podstawie statystyki w fizykacie miejskim wyznaczano roczną oraz miesięczną „normę” zachorowań dla danej choroby, a jej przekroczenie sygnalizowało możliwość pojawienia się albo istnienia epidemii ${ }^{28}$.

We Lwowie pierwszym ogniwem w łańcuchu osób władnych oraz zobowiązanych działać w przypadku epidemii był fizyk miejski. W razie pojawienia się choroby zakaźnej na podległym sobie terenie miał on osobiście ocenić sytuację, ustalić przyczyny, zawiadomić prezydenta miasta, podjąć niezbędne działania. W przypadku, gdyby to przekraczało jego możliwości czy pełnomocnictwa, miał przedstawić odpowiednie propozycje prezydentowi miasta ${ }^{29}$. Pojawienie się $\mathrm{w}$ mieście epidemii

${ }^{26}$ W ustawodawstwie uwzględniano choroby zakaźne człowieka oraz choroby odzwierzęce. Dla niektórych chorób istniały odrębne przepisy, np. dla dżumy, cholery, błonicy itd. Dezynfekcja była obowiązkowa w przypadku cholery, błonicy, szkarlatyny, gruźlicy itd. Istniały też dokładniejsze przepisy związane z rozprzestrzenianiem się chorób zakaźnych na terenach przygranicznych, szkół, kolei itd. Za niewykonywanie rozporządzeń mających na celu zapobieganie przenoszeniu się chorób zakaźnych, a także za ukrywanie oraz przywłaszczanie rzeczy przeznaczonych do zniszczenia lub oczyszczenia, artykuły 393-397 i 431 ustawy karnej przewidziały karę pieniężną oraz areszt, zob.: Zbiór ustaw i rozporządzeń sanitarnych ze szczególnem uwzględnieniem Galicji $i$ W. Księstwa Krakowskiego, zest. J. Barzycki, Z. Lachowicz, L. Kruszyński, t. 2, Lwów 1899, s. 1-180; Ustawa karna z dnia 27 maja 1852. Część druga. O występkach i przekroczeniach, oprac. J. Sułkowski, Kraków 1906, s. 153-157, 187-188.

${ }^{27}$ Zbiór ustaw i rozporządzeń administracyjnych w Królewstwie Galicyi i Lodomeryi z Wielkiem Księstwem Krakowskim obowiazujących z wyciagiem orzeczeń c.k. Trybunału administracyjnego. Podręcznik dla organów c.k. Władz rzadowych $i$ władz autonomicznych, ułożył i wydał J.R. Kasparek, t. 3, Lwów 1885, s. 2307-2308.

${ }^{28}$ E. Piasecki, Epidemia płonicy w mieście Lwowie w latach 1907-1909. Z polecenia komisyi, wybranej przez Radę królewskiego stołecznego miasta Lwowa dnia 27 sierpnia 1908, „Głos Lekarzy" 1909, 13, s. 149-150.

${ }^{29}$ Instrukcja służbowa dla naczelnego lekarza miejskiego, „Dziennik Ustaw i Rozporządzeń Krajowych dla Królestwa Galicyi i Lodomeryi wraz z Wielkiem Księstwem Krakowskiem" 1894, 1, s. 1-6. 
ogłaszał Magistrat. Także on wskazywał niezbędne działania przeciwepidemiczne i zarządzał szpitalem zakaźnym w mieście ${ }^{30}$. Gdyby działania gminy w przypadku epidemii były niewystarczające, prezydent powinien zawiadomić o tym władzę krajową (§ 58 Statutu miejskiego). W sprawach zdrowia po fizykacie pierwszą instancją dla Lwowa był tzw. departament sanitarny Namiestnictwa jako organ kontrolny oraz nadzorczy. Rolę eksperta i doradcy w Namiestnictwie pełniła Krajowa Rada Zdrowia.

\section{Szkarlatyna jako choroba zakaźna w XIX wieku}

Szkarlatyna (płonica) należy do epidemicznych chorób zakaźnych, które w XIX w. często powodowały śmierć oraz ciężkie powikłania. Wybuchy epidemii szkarlatyny są znane w Europie co najmniej od początku czasów nowożytnych. W wieku XVIII do początku XIX choroba miała przeważnie łagodny przebieg ${ }^{31}$, jednak zmieniło się to w latach 1820-1830. Między rokiem 1820 a 1880 w Europie i Ameryce Północnej miała miejsce pandemia i kilka ciężkich epidemii o wysokim poziomie śmiertelności ${ }^{32}$. Choroba ta stała się wtedy najbardziej rozpowszechnioną zakaźną, śmiertelną chorobą dziecięcą. Pod koniec XIX w. poziom śmiertelności stopniowo zaczął się zmniejszać ${ }^{33}$.

Szkarlatyna przeważnie dotykała dzieci w wieku od 3 do 8 lat ${ }^{34}$. Powikłanie w wyniku ciężkiej formy choroby mogło spowodować uszkodzenie słuchu, serca albo nerek. Szkarlatyna przenosi się drogą kropelkową, przez odzież, przedmioty użytku codziennego, kurz, a także mleko. Głównymi środkami prewencyjnymi w walce przeciw rozprzestrzenianiu się

30 Miasto Lwów w okresie samorządu, 1870-1895, Lwów 1896, s. 538.

31 A.R. Katz, M.D. Morens, Severe Streptococcal Infections in Historical Perspective, „Clinical Infectious Diseases” 14, 1992, 1, s. 299.

32 A.C. Swedlund, A.K. Donta, Scarlet Fever Epidemics of the Nineteenth Century. A Case of Evolved Pathogenic Virulence?, w: Human Biologists in the Archives. Demography, Health, Nutrition and Genetics in Historical Populations, red. D.A. Herring, A.C. Swedlund, Cambridge 2003, s. 159.

${ }^{33}$ Ten spadek śmiertelności częściowo spowodowany był rozwojem praktyk zdrowia publicznego, a także polepszeniem wyżywienia oraz innymi czynnikami wynikającymi z wyższego statusu socjalnego i ekonomicznego niektórych grup ludności. Przy tym za kluczowy powód uważa się cykliczną wirulencję bakterii Streptococcus pyogenes grupy A, wywołującą szkarlatynę, która tłumaczy fluktuacje czasowe i geograficzne choroby, A.R. Katz, M.D. Morens, op. cit., s. 300, 305; A.C. Swedlund, A.K. Donta, op. cit., s. 159-174; A. Hardy, The Epidemics Streets. Infectious Disease and the Rise of Preventive Medicine. 1856-1900, New York 1993, s. 58-59.

${ }^{34}$ M. Baranowski, Hygiena przystępnie wyłożona, red. J. Szpilman, Lwów 1891, s. 310. 
Wykres 2. Przebieg epidemii szkarlatyny we Lwowie, wrzesień 1907 - kwiecień 1910 r. Liczba zachorowań według miesięcy (liczby bezwzględne)

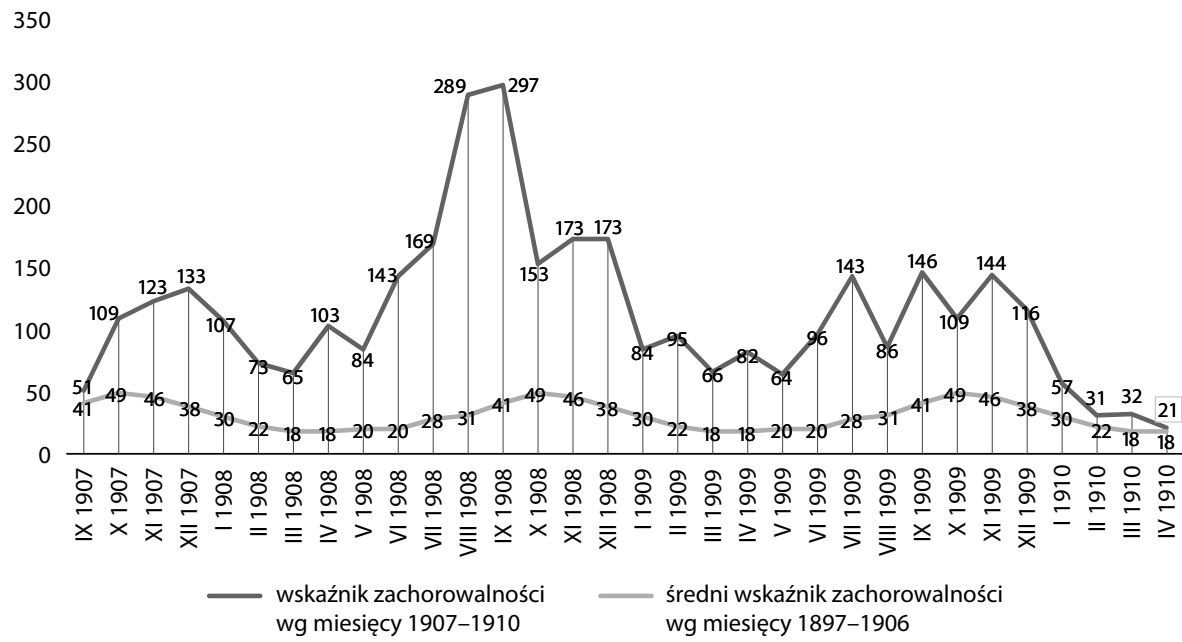

Źródło: Wiadomości statystyczne o mieście Lwowie, Lwów 1910, 1911, 1914; E. Piasecki, Epidemia płonicy w mieście Lwowie w latach 1907-1909. Z polecenia komisyi, wybranej przez Radę królewskiego stołecznego miasta Lwowa dnia 27 sierpnia 1908, „Głos Lekarzy” 1909, 13, s. 149-151.

tej choroby były izolacja chorego, zwłaszcza w szpitalach chorób zakaźnych, oraz dezynfekcja ${ }^{35}$.

W omawianym okresie w Galicji choroba występowała epidemicznie w latach $1896,1897,1898,1902,1903,1908$ oraz 1909. W tym czasie w ciągu roku umierało na nią średnio ok. 10,5 tys. osób ${ }^{36}$. We Lwowie w latach 1875-1913 szkarlatyna miała bardziej agresywny charakter w 1876, 1880, 1895, 1898, 1908, 1909 oraz 1912 r. Wielka epidemia przypadła na lata 1907-1910, a potem znów powtórzyła się w latach 1911-1912 ${ }^{37}$.

Do analizy epidemii szkarlatyny 1907-1910 ówcześni lekarze wykorzystywali dane statystyczne za dziesięciolecie 1897-1906 (wykres 2). Średnio w ciągu tego okresu corocznie chorowały 363 osoby, a umierało $-69^{38}$. Średnia comiesięczna stopa zachorowalności stanowiła

35 A. Hardy, op. cit., s. 56-79; M. Baranowski, op. cit., s. 391; Є. Озаркевич, Порадник гігієнічно-лікарський. Недуги пошестні, Львів 1911, s. 23-29.

${ }^{36}$ Zob. Rocznik statystyki Galicyi, Lwów 1887, 1889, 1891, 1893, 1898, r. 1-5; Podręcznik statystyki Galicyi, Lwów 1900, t. 6, cz. 1; 1903, t. 7, cz. 1; 1908, t. 8, cz. 1; 1913, t. 9, cz. 1.

37 Zob. A. Pawlikowski, op. cit., t. 1-2; Rocznik statystyki Galicji, 1891, r. 3; Wiadomości statystyczne o mieście Lwowie, Lwów 1874, 1876, 1877, 1892, 1893, 1895, 1897, 1905, 1907, 1910, 1911, 1914, 1926; Miasto Lwów w okresie samorząu.

38 W. Legeżyński, Stosunki zdrowotne, s. 435. 
30 przypadków. Największa liczba chorych zwykle przypadała na miesiące jesienne i spadała w grudniu-styczniu. W lipcu 1907 r. było zarejestrowanych 13 przypadków szkarlatyny, w sierpniu - 19, co było nawet poniżej średniego wskaźnika dla tych miesięcy. Natomiast we wrześniu wskaźnik wynosił 51 i wzrastał w następnych miesiącach. Najwyższy poziom liczby chorych osiągnęły w sierpniu-wrześniu 1908 r. i wróciły do skali sprzed epidemii dopiero w kwietniu $1910 \mathrm{r}$.

\section{Wybory do Rady Miejskiej w 1908 roku}

Ponieważ istniał pewien związek między walką z epidemią, dyskusją prasową a wyborami miejscowymi 1908 r., zatrzymamy się na tych ostatnich. Na omawiany okres przypadły dwie kampanie wyborcze - do Sejmu Galicyjskiego i do Lwowskiej Rady Miejskiej, a także zabójstwo namiestnika hrabiego Andrzeja Potockiego przez ukraińskiego studenta Myrosława Siczyńskiego (Miroslav Sičins'kij). Część działaczy politycznych brała udział zarówno w miejscowym, lwowskim, jak i krajowym życiu politycznym. We Lwowie w 1908 r. większe komitety wyborcze pracowały jednocześnie na dwie kampanie - sejmową oraz miejską. Z powodu wyborów do Sejmu wybory do Rady z lutego zostały przeniesione na marzec, a później wyznaczono jeszcze dodatkowe wybory do Rady w maju ${ }^{39}$. Pierwsze posiedzenie nowej Rady odbyło się dopiero 20 czerwca 1908 r. $^{40}$

W miejskim życiu politycznym uczestniczyło również kilku lekarzy higienistów. Przez wiele lat funkcję radnego pełnił inicjator założenia i pierwszy redaktor czasopisma Lwowskiego Towarzystwa Higienicznego „Przegląd Higieniczny” - Józef Szpilman ${ }^{41}$. Po przeprowadzce do Lwowa na początku XX w. aktywną działalność prowadził Szczepan Mikołajski. Po raz pierwszy został on lwowskim radnym w 1905 r. i wchodził do Rady przez wszystkie następne kadencje aż do początku wojny ${ }^{42}$.

${ }^{39}$ Kronika. Wybory do Rady miejskiej, „Dziennik Lwowski” 1908, 1, s. 16; Obwieszczenie (L. 769/908. Pr.), „Dziennik Lwowski” 1908, 10, s. 206-208.

401 posiedz. R.m., „Dziennik Lwowski” 1908, 13, s. 266.

${ }^{41}$ Józef Szpilman (1855-1920) - lekarz medycyny i weterynarii, profesor i rektor Akademii Weterynarii we Lwowie, członek wielu towarzystw. Od lat dziewięćdziesiątych z przerwami do 1911 r. wybierano go do Lwowskiej Rady Miejskiej, S.T. Sroka, Szpilman Józef Baltazar, PSB, t. 48, Warszawa-Kraków 2012-2013, s. 635-637.

${ }^{42}$ Szczepan Jan Mikołajski (1861-1929) - lekarz, w 1902 r. przeniósł się do Lwowa, redaktor czasopisma „Głos Lekarzy”, współpracował z „Kurierem Lwowskim”. Należał do Stronnictwa Ludowego (SL) od czasu jego założenia w 1895 r., później znalazł się we „frondzie” lwowskiej Polskiego Stronnictwa Ludowego, po rozłamie w PSL „Piast”. Kilka razy wybierano go do Lwowskiej Rady Miejskiej. W PSB podano datę wyboru 1904 r., 
Podczas kampanii wyborczej w 1908 r. Mikołajski wystąpił z inicjatywą stworzenia komitetu wyborczego lekarzy. Celem było dodanie do składu Rady Miejskiej większej liczby radnych lekarzy. Mikołajski uważał, że potrzebne minimum to dziewięciu medyków, zamiast pięciu, jak było $\mathrm{w}$ tamtym momencie ${ }^{43}$. Jednak inicjatywa ta nie spotkała się $\mathrm{z}$ wielkim entuzjazmem wśród jego kolegów po fachu. Dlatego zrezygnowali oni z próby tak szerokiej akcji przedwyborczej i rekomendowali innym komitetom wyborczym pięciu kandydatów lekarzy ${ }^{44}$.

W wyniku wyborów do nowego składu Lwowskiej Rady Miejskiej weszło sześciu lekarzy - trzech członków Lwowskiego Towarzystwa Higienicznego: Mikołajski, Szpilman, Eugeniusz Piasecki ${ }^{45}$, a także Wilhelm Pisek, dyrektor Szpitala Powszechnego Krajowego we Lwowie Józef Starzewski oraz członek Lwowskiej Rady Wyznaniowej Izraelickiej, wiceprezes Rady szpitala izraelickiego Jakub Mahl (zmarł w 1910 r. przed upływem swojej kadencji ${ }^{46}$. Nowo wybrani zostali Pisek i Starzewski. Za wspólną zgodą lekarze rozdzielili się na pięć sekcji Rady Miejskiej. W latach poprzednich wszyscy radni lekarze wchodzili wyłącznie do tzw. sekcji „sanitarnej” ${ }^{47}$. Wszyscy natomiast weszli w skład Komisji Zdrowotnej"8.

Chociaż oddzielnego komitetu lekarskiego nie udało się utworzyć, kwestie zdrowia publicznego w mieście weszły do programów przedwyborczych

Łukasz Tomasz Sroka podaje 1906 r., lecz w tych latach wyborów do Rady Miejskiej nie było. Po raz pierwszy wybrano go na radnego w 1905 r. na sześć lat, A. Pilch, Mikołajski Szczepan Jan, PSB, t. 21, Wrocław 1976, s. 156-157; Ł.T. Sroka, op. cit., s. 486; Spis członków Rady, „Dziennik Lwowski” 1906, 1, s. 2.

${ }^{43}$ S. Mikołajski, Lekarze lwowscy wobec wyborów do Rady miejskiej, „Głos Lekarzy” 1907, 24, s. 2-3.

${ }^{44}$ Kronika. Kandydatury lekarzy do Lwowskiej Rady miejskiej, „Głos Lekarzy” 1908, 3, s. 7.

${ }^{45}$ Eugeniusz Witold Piasecki (1872-1947) - lekarz, aktywny popularyzator wychowania fizycznego, założyciel Towarzystwa Zabaw Ruchowych. Początkowo należał do Polskiej Partii Socjalistycznej, później - do Stronnictwa Demokratyczno-Narodowego. Kilka razy wybierano go do Lwowskiej Rady Miejskiej. W PSB podano datę wyboru 1906 r., Łukasz Tomasz Sroka podaje 1909 r., lecz w tych latach wyborów do Rady nie było. Po raz pierwszy wybrano go na radnego na wyborach kolejnych 1908 r. na trzy lata, Ł.T. Sroka, op. cit., s. 488; Obwieszczenie, „Dziennik Lwowski” 1908, 11, s. 228; S.M. Brzozowski, Piasecki Eugeniusz Witold, PSB, t. 25, Wrocław-Warszawa-Kraków 1980, s. 774-777; https://www.ipsb.nina.gov.pl/a/biografia/eugeniusz-witold-piasecki (dostęp: 5 III 2021).

${ }^{46}$ Kronika. Radni m. Lwowa, „Kurier Lwowski” 1908, 243, s. 3; Kronika, „Głos Lekarzy” 1910, 10, s. 117.

${ }^{47}$ Kronika. Lekarze we Lwowskiej Radzie miejskiej, „Głos Lekarzy” 1908, 13, s. 6; S. Mikołajski, Działalność lekarzy w Radzie miejskiej (1905-1911) a postęp sanitarny w mieście Lwowie, „Głos Lekarzy” 1910, 23, s. 1.

486 posiedzenie Rady miejskiej z 9-go lipca 1908 r., „Dziennik Lwowski” 1908, 14, s. 299. 
Komitetu Reformy Gospodarki Miejskiej oraz Powszechnego Komitetu Obywatelskiego. Pierwszy znajdował się pod wpływem ludowców. Dość aktywnie wspierał go „Kurier Lwowski”. Wśród ludowców jednym z najaktywniejszych działaczy był Mikołajski, który razem ze Szpilmanem był zastępcą kierownika komitetu ${ }^{49}$. Powszechny Komitet Obywatelski był pod wpływem endecji, aktywnie popierał go dziennik lwowski „Słowo Polskie”. Z tego komitetu w wyborach kandydował także Piasecki.

Komitet Reformy Gospodarki Miejskiej żądał reorganizacji miejskiej służby zdrowia, uregulowania opieki nad ubogimi czy nieuleczalnie chorymi oraz starszymi ludźmi. Proponowano także zmiany w zakresie walki z chorobami zakaźnymi oraz higieny szkolnej. Wśród ważnych instrumentów „uzdrowotnienia” miasta wskazywano wypracowanie planu regulacji przestrzeni miasta (zwłaszcza dzielnicy III), rozszerzenie wodociągów, budowę tanich mieszkań dla robotników i klasy średniej. Ważnym punktem była budowa łaźni ludowych, zwłaszcza w dzielnicach, w których mieszkali robotnicy ${ }^{50}$. W ramach kampanii proasymilacyjnego Mikołajski, na żądanie redakcji żydowskiego czasopisma asymilatorskiego „Jedność", przygotował artykuł o stanie zdrowia wśród Żydów lwowskich. Jednym z kluczowych zaleceń było „uzdrowotnienie” dzielnicy III, którą określano jako „wylęgowisko i rozsadnik wszelkich chorób zakaźnych”51.

Powszechny Komitet Obywatelski także domagał się reformy służby zdrowia w mieście, która m.in. obejmowałaby zwiększenie liczby dzielnic sanitarnych, zmianę instrukcji dla lekarzy miejskich i wprowadzenie stanowiska lekarza szkolnego w każdej placówce ${ }^{52}$. Poza tym uwagę poświęcono także dzielnicy III miasta - na spotkaniu z wyborcami z tej dzielnicy przedstawiciele komitetu dyskutowali na temat kwestii zdrowia publicznego. Piasecki analizował stan spraw z punktu widzenia higieny oraz określił plan działań dla poprawienia sytuacji53.

W wyniku wyborów przedstawiciele obu komitetów weszli do rady miejskiej. Pierwsi sformowali Klub Reformy, a drudzy - Klub „Centrum”, do którego, oprócz Piaseckiego, należeli także Mahl i Starzewski ${ }^{54}$.

${ }^{49}$ Kronika. Wybory do Rady m., „Kurier Lwowski” 1908, 116, s. 3.

${ }^{50}$ Komitet reformy gospodarki miejskiej, „Kurier Lwowski” 1908, 48, s. 2-3; Lekarze przy wyborach Rady miejskiej we Lwowie, „Głos Lekarzy” 1908, 8, s. 1-3.

${ }^{51}$ S. Mikołajski, Stosunki zdrowotne wśród żydów lwowskich, „Jedność" 1908, 6, s. 2-3.

${ }^{52}$ Sprawozdanie klubu radnych (centrum) z czynności w Radzie miasta Lwowa za trzechlecie 1905-1908, Lwów 1908.

${ }^{53}$ Wybory do Rady miejskiej. Zgromadzenie wyborców III dzielnicy, „Słowo Polskie” 1908, 132, s. 4.

${ }^{54}$ Z Rady miejskiej, „Słowo Polskie” 1908, 342, s. 1; Kronika. Rada miejska, „Gazeta Narodowa" 1908, 142, s. 2. 
Oba kluby były opozycyjne w stosunku do tzw. Strzelnicy (Koła Mieszczańskiego) - największego i najbardziej wpływowego stronnictwa w Radzie, do którego w tym czasie należeli prezydent miasta Stanisław Ciuchciński oraz wiceprezydent Tadeusz Rutowski ${ }^{55}$.

\section{Epidemia we Lwowie: działania przeciwepidemiczne i reakcja lwowian}

W listopadzie 1907 r. tzw. departament sanitarny Magistratu rozpatrywał kwestię epidemii szkarlatyny we Lwowie ${ }^{56}$. W grudniu tego roku na żądanie Namiestnictwa władze miejskie otworzyły tzw. baraki choleryczne, czyli miejski szpital epidemiczny przy ul. Janowskiej ${ }^{57}$. Otwarcie poprzedziła decyzja o wysłaniu do Ministerstwa Spraw Wewnętrznych odwołania od wniosku Namiestnictwa, mówiącego, że we Lwowie istnieje epidemia szkarlatyny i szpital epidemiczny jest potrzebny. Niebawem jednak Magistrat wycofał się z apelacji, ale z zastrzeżeniem, że należy pilnować zwrotu kosztów leków. Oprócz otwarcia szpitala epidemicznego zdecydowano także o opublikowaniu ulotki o szkarlatynie w nakładzie 1000 egzemplarzy ${ }^{58}$. Baraki zostały zamknięte w marcu $1908 \mathrm{r}^{59}$. Możemy przypuszczać, że Magistrat niezbyt chętnie otwierał szpital, który oprócz dodatkowych kłopotów, generował też wydatki.

Komisja Zdrowotna w pierwszej połowie 1908 r. zebrała się tylko w styczniu ${ }^{60}$. Oczywiście, wybory miały wpływ na pracę urzędu miejskiego

55 Wybory do Rady miejskiej, „Kurier Lwowski” 1908, 146, s. 1; Z Rady miejskiej, „Słowo Polskie” 1908, 342, s. 1; Wybory do Rady miejskiej, „Słowo Polskie” 1908, 135, s. 2.

${ }^{56}$ Magistrat. Posiedzenie 13 listopada. Dep IX., „Dziennik Lwowski” 1907, 22, s. 542.

${ }^{57}$ Baraki przy ul. Janowskiej 104 nie zachowały się. Dzisiaj jest to ul. Szewczenki. Dwa drewniane, parterowe baraki wzniesiono obok cmentarza Janowskiego w $1892 \mathrm{r}$. na wypadek niebezpieczeństwa epidemii cholery, dlatego otrzymały nazwę „baraki choleryczne”. Inne nazwy - miejskie pawilony izolacyjne, baraki epidemiczne, miejski szpital epidemiczny. Oba pawilony mogły wygodnie pomieścić 92 chorych. oddział dla chorób zakaźnych w szpitalu powszechnym miał 49 łóżek, oddział szpitala św. Zofii dla dzieci - 26 łóżek. Zwykle te oddziały w obu szpitalach były przepełnione. Wojskowi mieli swój szpital przy ul. Łyczakowskiej 26. Baraki otwierano w razie konieczności dla chorych na choroby zakaźne, jeżeli brakowało miejsca w szpitalach, W. Legeżyński, Stosunki zdrowotne, s. 403; P. Franaszek, Zdrowie publiczne, s. 89.

${ }_{58}$ Magistrat. Posiedz. 4 grudnia 1907. Depart. IX. Lm. 121.946/07, „Dziennik Lwowski” 1907, 24, s. 586; Magistrat. Posiedz. 14 grudnia 1907. Depart. IX. Lm. 121.946/07, „Dziennik Lwowski" 1907, 24, s. 588.

${ }^{59}$ Komisja zdrowotna miejska w sprawie szkarlatyny, „Kurier Lwowski” 1908, 400, s. 2.

${ }^{60}$ Komisja zdrowotna stała. Posiedz. dnia 18 stycznia 1908, „Dziennik Lwowski” 1908, 3, s. 50; Z obrad lwowskiej Rady zdrowia, „Kurier Lwowski” 1908, 32, s. 2. 
w tym czasie. Ponieważ zwierzchnikiem komisji był Rutowski jako wiceprezydent miasta, do niego należał obowiązek zwoływania posiedzeń. To on mówił później o wyborach jako o przyczynie braku posiedzeń61

Po zamknięciu baraków w marcu, w następnych miesiącach zachorowalność znów wzrosła i była wyraźnie wyższa od wskaźników średnich (wykres 1). Na podstawie reskryptu Namiestnictwa 2 lipca Magistrat powtórnie otworzył miejski szpital epidemiczny przy ul. Janowskiej. Baraki były przeznaczone dla stałych mieszkańców Lwowa chorych na szkarlatynę, którzy nie mogli leczyć się w domu, a zabrakło dla nich miejsc w szpitalu dziecięcym św. Zofii oraz w Szpitalu Powszechnym Krajowym $^{62}$.

Jednak poważniej uwagę urzędu miejskiego na problem zwróciło powiadomienie o zaniedbaniu lekarskim w szpitalu epidemicznym, które złożono na posiedzeniu Rady Miejskiej 9 lipca 1908 r. Jak dowiadujemy się z organu prasowego Rady Miejskiej, „Dziennika Lwowskiego”, dyskusję wywołała uwaga radnego, że baraki otworzono „z powodu wybuchłej epidemii szkarlatyny". W odpowiedzi prezydent miasta Ciuchciński stwierdził, że poziom zachorowalności jest typowy dla Lwowa i nie ma epidemii, dlatego słowa radnego mogą wywołać niepotrzebny popłoch w mieście ${ }^{63}$. Natomiast radny Mikołajski zaprzeczył temu twierdzeniu i zaproponował zwołanie miejskiej Komisji Zdrowotnej. Po tym posiedzeniu Rady urząd miejski podjął widoczne działania związane ze szkarlatyną, choroba była także przedmiotem dyskusji w prasie miejskiej. Szczyt epidemii, a także największa intensywność wysiłków przeciwepidemicznych przypadły na sierpień-wrzesień $1908 \mathrm{r}$. W następnych miesiącach miasto działało w ramach wprowadzonych środków, regulując je zgodnie $\mathrm{z}$ dynamiką epidemii.

W połowie lipca na posiedzeniu Komisji Zdrowotnej zdecydowano o publicznym ogłoszeniu przez prasę otwarcia szpitala przy ul. Janowskiej, a lekarzy miejskich zobowiązano do odwiedzania co osiem dni domów, w których są chorzy, w celu ujawnienia nowych przypadków zachorowań ${ }^{64}$. Bardziej systemowe i surowsze działania zostały wypracowane i wprowadzone na przełomie sierpnia i września.

26 sierpnia odbyło się posiedzenie Komisji Zdrowotnej z udziałem krajowego referenta sanitarnego Józefa Merunowicza. Spotkaniu towarzyszyła dość ostra dyskusja. Referent oraz przedstawiciele władz

\footnotetext{
61 Audiatur et altera pars. Z prezydium miejskiego, „Słowo Polskie” 1908, 408, s. 4.

62 Ogłoszenie, „Dziennik Lwowski” 1908, 15, s. 334.

${ }^{63}$ 6. Posiedz. Rady miejskiej z 9-go lipca 1908 roku, „Dziennik Lwowski” 1908, 14, s. 294.

${ }^{64}$ Z miejskiej Rady zdrowia we Lwowie, „Kurier Lwowski” 1908, 325, s. 2-3.
} 
miejskich, zwłaszcza wiceprezydent, przerzucali się oskarżeniami o niedbałość i bezczynność. Z opisu sporu, który zamieścił „Kurier Lwowski" możemy wnioskować, że największe niezadowolenie Ciuchcińskiego i Rutowskiego wywołało żądanie Namiestnictwa, żeby Lwów zatrudnił siedmiu lekarzy epidemicznych na swój koszt. Podjęte decyzje w sprawie działań przeciwepidemicznych zostały wypracowane przy ingerencji Merunowicza.

Ze sprawozdania fizyka, Wiktora Legeżyńskiego, wygłoszonego na posiedzeniu, dowiadujemy się, że do pracy w fizykacie oraz szpitalu epidemicznym dodatkowo zaangażowano dwóch lekarzy. W przypadku doniesienia o szkarlatynie od lekarza prywatnego, fizykat wysyłał do chorego funkcjonariusza sanitarnego, a w niektórych przypadkach lekarza miejskiego. Celem było ustalenie źródła infekcji, zawiadomienie wszystkich mieszkańców domu o chorobie oraz pozostawienie instrukcji o sposobach dezynfekcji. W końcu sierpnia w mieście było 17 domów, w których jednocześnie znajdowało się kilku chorych. Do opieki nad nimi zostali wyznaczeni lekarze miejscy. Po zakończeniu choroby funkcjonariusz sanitarny pod nadzorem lekarza przeprowadzał dezynfekcje mieszkania ${ }^{65}$.

W rezultacie 1 września Magistrat zobowiązał lekarzy, dorosłych członków rodzin, dyrektorów szkół, właścicieli zakładów przemysłowych itd., aby zawiadamiali w ciągu 24 godzin fizykat miejski o każdym przypadku szkarlatyny, który będzie im znany. Oprócz tego, na domach lub na drzwiach mieszkań, w których byli chorzy na szkarlatynę, mieli oni umieszczać tabliczki kartonowe z napisem „Ostrzeżenie - Szkarlatyna - Wstęp wzbroniony". Za pilnowanie, aby ostrzeżeń nikt nie zrywał, odpowiadał dozorca domu. Naruszającym prawo groziła kara do 200 koron albo areszt do 14 dni. Także gmina obiecała dostarczyć biednym rodzinom darmowy płyn do dezynfekcji oraz zapewnić bezpłatną dezynfekcję rzeczy i pokoju, w którym przebywał chory ${ }^{66}$. Magistrat polecał lekarzom prowadzącym wolną praktykę, aby w sytuacji, kiedy nie było możliwości izolacji dzieci w domu, kierować je do baraku epidemicznego ${ }^{67}$. „Dziennik Lwowski” opublikował przygotowaną przez Magistrat instrukcję o szkarlatynie, wyjaśniającą szczegóły choroby, sposób opieki nad chorym, środki izolacji oraz dezynfekcji, a także omawiającą sposoby

65 Komisja zdrowotna, „Dziennik Lwowski” 1908, 17, s. 367; Miejska komisja zdrowotna w sprawie szkarlatyny, „Kurier Lwowski” 1908, 399, s. 1; dokończenie: 400, s. 2-3; 402, s. 6-7.

${ }^{66}$ Ogłoszenie (Lm. 89.616/08. IX), „Dziennik Lwowski” 1908, 18, s. 405.

67 Ogłoszenie (Lm. 94.948/08. IX), „Dziennik Lwowski” 1908, 19, s. 446. 
zapobiegania zakażeniu ${ }^{68}$. Od początku września została zorganizowana służba pogotowia ratunkowego, która pracowała do szóstej wieczorem w Departamencie sanitarnym, a w fizykacie - do ósmej ${ }^{69}$.

4 września miasto zatrudniło siedmiu lekarzy epidemicznych. Kolejny sprawował nadzór nad dezynfekcją. W ciągu pierwszego tygodnia września lekarze epidemiczni dokonali inspekcji wszystkich znanych w tamtym momencie przypadków choroby i rozpoczęli nadzorowanie chorych leczących się w domu. Na żądanie fizykatu także dwie zakonnice odwiedzały ubogie rodziny, których matki przebywały w barakach epidemicznych $\mathrm{z}$ chorymi dziećmi ${ }^{70}$.

Najwięcej uwagi poświęcano uczniom i przedszkolakom. Jeszcze w połowie sierpnia Magistrat zwrócił się do Rady Szkolnej Krajowej z żądaniem opóźnienia otwarcia szkół we Lwowie do 15 września ${ }^{71}$. Po kilku dniach Rada Szkolna Krajowa uchwaliła odłożenie początku roku szkolnego w szkołach elementarnych. Postanowiono także zwrócić się do Ministerstwa Edukacji z prośbą o przełożenie początku roku szkolnego na połowę września czterech młodszych klas szkół średnich. Klasy starsze miały rozpocząć nauczanie normalnie, ponieważ chorowało tylko siedmiu uczniów w wieku powyżej 15 lat $^{72}$. Ministersto zezwoliło na takie rozwiązanie. Oprócz Lwowa, podobne działania wprowadzono także w Tarnopolu i wielu mniejszych miasteczkach ${ }^{73}$.

Na początku września Rada Miejska na podstawie zaleceń Komisji Zdrowotnej próbowała przekonać Ministerstwo Edukacji do zamknięcia również starszych klas, lecz prośba ta nie została spełniona, co wywołało krytyczne komentarze w prasie ${ }^{74}$. Niezadowolenie $z$ tej decyzji wyraził m.in. „Goniec Polski”. Ironizując, że „pan funkcjonariusz” pewnie jest nieżonaty, autor artykułu podkreślił, że w rodzinach są dzieci w różnym wieku. Starsze, które pójdą do szkoły, mogą przynieść stamtąd chorobę

68 Obwieszczenie (Lm. 92.205/08.IX), „Dziennik Lwowski” 1908, 19, s. 446.

69 „Korespondencja Ratuszowa”, nr 1, Lwów 1 IX 1908, Центральний державний історичний архів України у Львові (dalej: ЦДІА України у Львові), f. 146, op. 8a, sp. 202, k. 2.

${ }^{70}$ Kronika. Epidemja szkarlatyny we Lwowie, „Kurier Lwowski” 1908, 419, s. 2; Płonica we Lwowie, „Goniec Polski” 1908, 495, s. 3.

${ }^{71}$ Magistrat. 41 posiedz. 12 sierpnia 1908, „Dziennik Lwowski” 1908, 16, s. 350.

72 Różne wiadomości, „Lwowski Tygodnik Lekarski” 1908, 34, s. 389; Kronika. Szkarlatyna we Lwowie, „Kurier Lwowski” 1908, 397, s. 2.

73 Zarzadzenie Rady szkolnej krajowej w sprawie epidemji szkarlatyny, „Kurier Lwowski” 1908, 399, s. 3; Kronika. Zarządzenie Rady szkolnej krajowej w sprawie epidemii szkarlatyny, „Goniec Polski” 1908, 485, s. 4.

${ }^{74}$ Komisja zdrowotna, posiedz. dnia 4 wrzesnia 1908, „Dziennik Lwowski” 1908, 18, s. 392. 
młodszym ${ }^{75}$. Prasa pisała także o tym, że niektóre prywatne instytucje edukacyjne i zawodowe rozpoczęły nauczanie wcześniej, mimo zakazu ${ }^{76}$. Jak stwierdzano później na podstawie statystyki, otwarcie szkół w danym terminie nie miało wielkiego wpływu na rozprzestrzenianie się choroby właśnie wśród uczniów ${ }^{77}$.

Na podstawie uchwały Komisji Zdrowotnej Magistrat na początku września zwrócił się do lekarzy miejskich, aby na czas epidemii każdego tygodnia dokonywali oni inspekcji w szkołach i raportowali o wynikach ${ }^{78}$. W tym czasie w szkołach kolportowano informatory o szkarlatynie, żeby nauczyciele poznali objawy początku choroby ${ }^{79}$.

Oprócz zamknięcia szkół, Krajowa Rada Szkolna we współpracy z Namiestnictwem pod koniec sierpnia wydała rozporządzenie dotyczące uczniów starszych klas. W przypadku pojawienia się szkarlatyny w domu mieli oni zakaz chodzenia do szkoły, póki nie zaświadczą fizykatowi, że wyprowadzili się z domu, albo że ich współlokatorzy są zdrowi. Także miasto otrzymało instrukcję, aby informować kierowników szkół o każdym przypadku szkarlatyny w rodzinach uczniów, a z końcem miesiąca każdy nowy przypadek szkarlatyny u ucznia zgłaszano w odpowiedniej szkole $^{80}$. W połowie września fizyk razem z inspektorem sanitarnym dokonali inspekcji szkół w najbardziej zakażonych częściach miasta ${ }^{81}$. Wraz z otwarciem placówek Rada Szkolna Krajowa zezwoliła rodzicom uczniów szkół podstawowych i klas młodszych szkół średnich, aby nie posyłali dzieci na lekcje, a tylko złożyli wyjaśnienia na piśmie dyrekcjom ${ }^{82}$.

W połowie września zamknięto także przedszkola (ochronki oraz tzw. ogródki freblowskie) i chedery. Później postanowiono podejmować decyzję o pracy każdej instytucji oddzielnie na podstawie sprawozdania fizykatu. Otwarte już przedszkola miały nadal działać pod nadzorem lekarza ${ }^{83}$.

Oczywiście, przełożenie początku roku szkolnego i zamknięcie przedszkoli miało wpływ na życie nie tylko rodzin uczniów i nauczycieli, lecz także na stan ekonomiczny właścicieli prywatnych instytucji

75 Ede, Z moich spostrzeżeń, „Goniec Polski” 1908, 484, s. 7.

${ }^{76}$ Kronika Lwowska. Szkarlatyna, „Gazeta Narodowa” 1908, 212, s. 2.

77 „Korespondencja Ratuszowa”, nr 67, Lwów 14 XI 1908, ЦДІА України у Львові, f. 146 , op. 8 a, sp. 202 , k. 8.

${ }^{78}$ Komisja zdrowotna. Posiedz. 4 września 1908, „Dziennik Lwowski” 1908, 18, s. 392; Magistrat. 48 posiedz. dnia 10 września 1908, „Dziennik Lwowski” 1908, 18, s. 398-399.

${ }^{79}$ Kronika Lwowska. Szkarlatyna, „Gazeta Narodowa” 1908, 207, s. 2.

80 Szkoły a szkarlatyna, „Słowo Polskie” 1908, 402, s. 6.

81 Szkarlatyna, „Słowo Polskie” 1908, 447, s. 6.

82 Kronika lwowska. Szkarlatyna, „Gazeta Narodowa” 1908, 214, s. 3.

83 Komisja zdrowotna. Posiedz. dnia 17 października 1908, „Dziennik Lwowski” 1908, 21, s. 502. 
edukacyjnych. Działania przeciwepidemiczne dotknęły praktycznie wszystkie sfery życia w mieście, szczególnie dotkliwe były te, w których odwoływano sią do przymusu. Jeżeli w rodzinie był chory na szkarlatynę, który leczył się w domu, urząd mógł żądać, żeby dorośli członkowie rodziny byli usunięci z pracy na cały czas trwania choroby, co mogło trwać nawet około sześciu tygodni. Leczenie w domu było dopuszczalne, jednak wymagało rzetelnej izolacji chorego w oddzielnym pomieszczeniu pod opieką tylko jednej osoby, dokładnego przestrzegania reguł higieny oraz dezynfekcji ${ }^{84}$. Zwykle nie było to osiągalne dla rodzin biednych. Członkowie rodziny także mogli wyprowadzić się na jakiś czas, na przykład zamieszkać czasowo u krewnych lub w hotelu. Żeby wrócić do pracy, trzeba było mieć zaświadczenie z miejskiego fizykatu, że dziecko jest już zdrowe. Od początku września gazety powiadamiały o zamknięciu decyzją Magistratu różnych pracowni, restauracji, hoteli, sklepów, odsunięciu od pracy pracowników różnych służb. Było to jedną z przyczyn ukrywania przez mieszkańców choroby i prób unikania w różny sposób wykonania rozporządzeń urzędu miejskiego. Na przykład, w listopadzie informowano o niezwykłym przypadku „ucieczki” dwóch lwowian. Najpierw ojciec zrezygnował z oddania dziecka do szpitala. Kiedy karetka epidemiczna przyjechała po chorego powtórnie, okazało się, że ojciec z dzieckiem uciekli do Tarnopola. Fizykat telegrafował do starostwa tarnopolskiego, żeby zawiadomić o uciekinierach. We Lwowie tymczasem w celu dezynfekcji odszukano dorożkę, z której skorzystali, żeby dostać się na dworzec ${ }^{85}$.

Oczywiście, czynniki ekonomiczne wpływały na postrzeganie tej choroby, jak i chorób zakaźnych w ogóle. Lekarz Eugeniusz Ozarkiewicz (Evgenì Ozarkevič) w popularnym poradniku lekarsko-higienicznym ostrzegał przed „niemądrym zwyczajem" nieizolowania zdrowych dzieci od chorych, a nawet odwrotnie - próbami, żeby "przechorowały razem”, co praktykowano przy szkarlatynie i odrze ${ }^{86}$. Te choroby dziecięce pojmowano jako nieuniknione oraz „obowiązkowe”, dlatego zakładano, że im szybciej wszystkie dzieci w domu przechorują, tym będzie lepiej. Korespondent „Gońca Polskiego” we wrześniu 1908 r. usłyszał na rynku lwowskim ciekawą rozmowę między przekupkami, która prawdopodobnie oddaje ówczesne poglądy oraz nastroje ludzi. Panie, których dzieci chorowały na błonicę i szkarlatynę, omawiały sposoby leczenia. Jako lek wymieniały miód z pieprzem, a także przebywanie na słońcu, natomiast

${ }^{84}$ Zob. np. Wskazówki celem zapobiegania płonicy, „Kurier Lwowski” 1908, 409, s. 1-2.

85 „Korespondencja Ratuszowa”, nr 73, Lwów 21 XI 1908, ЦДІА України у Львові, f. 146 , op. 8 a, sp. 202, k. 20.

${ }^{86}$ Є. Озаркевич, op. cit., s. 29-30. 
wezwania lekarza pragnęły uniknąć, ponieważ potrzebne były na to pieniądze, a oprócz tego fizykat mógł zabronić handlować oraz nie wypuścić małżonka kolejarza do pracy. W rezultacie rodzina mogła zostać bez środków do życia. Jak uważały podsłuchane rozmówczynie, do choroby są ,wyznaczeni”, dlatego choroba dla nich ,jak ma być, tak będzie, nawet jeśli wszyscy lekarze będą pilnować, a jak nie, to choć w jednym łóżku z chorym śpij”. Co do niebezpieczeństwa zakażenia innych, to jedna z pań uważała następująco: „moje słabują, mogą i inny słabować”7.

Mieszkańcy niezbyt chętnie oddawali swoje dzieci do szpitala epidemicznego. Jak informowała prasa, placówka przy ul. Janowskiej nie cieszyła się takim zaufaniem, jak szpital dziecięcy św. Zofii. Korespondenci prasowi przypuszczali, że dziecięcy funkcjonował od dawna i stale, był bardziej znany i zdobył zaufanie lwowian, jednak nie było tam możliwości zapewnienia wszystkim pomocy. Prasa opisywała przypadek, kiedy matka uciekła się do podstępu, żeby jej dziecko w końcu przyjęto do szpitala św. Zofii - powiadomiła ona, że z baraku do szpitala skierowały ją siostry zakonne, aczkolwiek, jak się okazało, nie było to prawdą.

Władze miejskie napominały, żeby nie wożono chorych dzieci komunikacją miejską, a zwracano się do lekarza dzielnicowego lub do szpitala powszechnego po specjalną karetkę epidemiczną, która przewoziła zakażonych. Oprócz tego, szpital epidemiczny przyjmował chorych na szkarlatynę tylko ze skierowaniem lekarza, ponieważ na miejscu nie było ambulatorium potrzebnego aby sprawdzić, czy dziecko rzeczywiście choruje na tę chorobę ${ }^{88}$.

Na początku września mieszkańcy powiadamiali o „amatorstwie” dozorców domów w związku ze wspomnianymi kartkami ostrzegawczymi. Zgodnie z rozporządzeniami Namiestnictwa, w tych domach, w których byli chorzy, dozorcom wydawano dwa egzemplarze zapasowych kartek ostrzegawczych. Prasa pisała o przypadkach, kiedy dozorcy samowolnie i bez wskazań przybijali te kartki na fasadach domów obok wejścia i w taki sposób szkodzili właścicielom mieszczących się tam sklepów i pracowni. Takiej szkody doznało zwłaszcza kilku właścicieli domów, którzy na początku miesiąca zmienili dozorców. Widocznie ci wykorzystywali czasowo dostępne pełnomocnictwa do załatwienia porachunków z właścicielami. Trudność sytuacji polegała na tym, że zdjąć takie karty miał prawo tylko pracownik Magistratu ${ }^{89}$.

${ }^{87}$ Jota, Jak zaradzić?, „Goniec Polski” 1908, 488, s. 3-4.

${ }^{88}$ Kronika. Epidemja szkarlatyny, „Kurier Lwowski” 1908, 439, s. 3; Szkarlatyna we Lwowie, „Słowo Polskie” 1908, 410, s. 6; Płonica we Lwowie, „Goniec Polski” 1908, 491, s. 3.

${ }^{89}$ Kronika. Epidemja szkarlatyny we Lwowie, „Kurier Lwowski” 1908, 419, s. 2. 
W celu uniknięcia rozprzestrzeniania się choroby, fizykat ogłaszał listę gmin, szczególnie podlwowskich, w których odnotowano przypadki szkarlatyny, żeby lwowianie nie kupowali produktów spożywczych u mieszkańców przywożących je stamtąd na rynki lwowskie. Najczęściej o zakażeniach dowiadywano się, kiedy do szpitala we Lwowie trafiał chory z którejś podmiejskiej gminy. Na przykład, w grudniu 1908 r. na szkarlatynę chorowali w Kleparowie, Zniesieniu, Kulparkowie, Kozielnikach, Solonce, Rześnie Ruskiej, Sknilowie ${ }^{90}$.

\section{Dyskusja w prasie}

Posiedzenie Rady Miejskiej 9 lipca i zwołanie Komisji Zdrowotnej 15 lipca zwróciły uwagę na epidemię oraz aktywizowały działalność władz miejskich. Oprócz otwarcia baraków epidemicznych pod koniec $1907 \mathrm{r}$. i ponownie w lipcu 1908 r., nie wiadomo o innych działaniach przeciwepidemicznych. Od początku tego roku szkarlatyna nie była także zauważana w prasie. Na przykład, „Kurier Lwowski”, który poświęcał miejskim wydarzeniom dużo uwagi, praktycznie nie zamieszczał wzmianek o chorobie we Lwowie w ciągu pierwszego półrocza 1908 r. O „panowaniu epidemicznym” szkarlatyny w mieście „Kurier” krótko informował na początku lipca ${ }^{91}$. Tak samo o rozpowszechnieniu się choroby pisała „Gazeta Narodowa”92.

Zainteresowanie prasy tematem rozpoczęło się w ciągu kilku dni po wspomnianym posiedzeniu Rady 9 lipca. Pojawił się komentarz o nasileniu się przypadków szkarlatyny w mieście i niejasnościach w zapewnieniach prezydenta o zwykłym poziomie zachorowalności ${ }^{93} .13$ lipca „Kurier Lwowski” zamieścił publikację pod tytułem Wielka epidemia szkarlatyny, która zintensyfikowała dyskusję. Autor artykułu krytycznie komentował obawy prezydenta przed wywołaniem popłochu w mieście. Wobec braku świadomości o szybkim rozprzestrzenianiu się chorób zakaźnych, informacji o sposobach przeciwdziałania im, publiczną debatę o epidemii nazwał „obowiązkiem obywatelskim" ${ }^{94} \mathrm{Na}$ początku sierpnia w „Słowie Polskim” pojawiła się wiadomość o epidemii

90 „Korespondencja Ratuszowa”, nr 100, Lwów 22 XII 1908, ЦДІА України у Львові, f. 146 , op. 8a, sp. 202, k. 59.

${ }^{1}$ Kronika. Szkarlatyna, „Kurier Lwowski” 1908, 315, s. 4.

${ }_{92}$ Kronika Lwowska. Szkarlatyna, "Gazeta Narodowa” 1908, 150, s. 2.

${ }^{93}$ Kronika Lwowska. Szkarlatyna, "Gazeta Narodowa” 1908, 159, s. 2.

94 Wielka epidemia szkarlatyny (płonicy), „Kurier Lwowski” 1908, 323, s. 2-3. 
szkarlatyny w Winnikach koło Lwowa oraz o wzroście liczby przypadków choroby we Lwowie ${ }^{95}$.

Szczyt dyskusji w dziennikach lwowskich: „Kurierze Lwowskim”, „Słowie Polskim”, „Gazecie Narodowej” przypadł na sierpień 1908 r. Gazety komentowały działania i bezczynność władzy - zarówno miejskiej, jak i krajowej, od czasu do czasu ustalając, która z nich ciężej zawiniła. Autorami niektórych tekstów byli lekarze ${ }^{96}$. Również same gazety zamawiały komentarze dotyczące epidemii u lekarzy higienistów ${ }^{97}$. Wymiana opinii wykraczała poza kwestię epidemii lwowskiej - w świetle problemu lokalnego pisano w ogóle o problemach prowincji. W ten sposób dyskusja nabrała charakteru medyczno-politycznego.

W dyskusjach sierpniowych ze wspomnianych trzech dzienników najwięcej uwagi szkarlatynie poświęcał „Kurier Lwowski”. Dość długie artykuły opierały się na dokładnych danych statystycznych oraz normach ustawowych przewidzianych na wypadek epidemii. Na ich podstawie „Kurier” krytykował pracę fizyka miejskiego i służby zdrowia w ogóle, szczególnie funkcjonariuszy sanitarnych. Krytykowano również wiceprezydenta Rutowskiego za niewłaściwą pracę Komisji Zdrowotnej, a Magistrat obwiniano o upartą niechęć do ogłoszenia w mieście stanu epidemii, co pozwoliłoby użyć wszystkich odpowiednich środków. Uwagi krytyczne kierowano także pod adresem Namiestnictwa za to, że toleruje działania Magistratu. „Kurier” pisał, że epidemia świadczy o „bankructwie całej sanitarnej administracji miejskiej”. W jednym z tekstów autor „obalał” mit stworzony przez, jak twierdzono, fizyka miejskiego, według którego odpowiedzialny za wszystkie nieszczęścia był „rząd” (administracja krajowa), a nie „autonomia” (urząd miejski) ${ }^{98}$. „Słowo Polskie" komentowało epidemię zauważalnie mniej, ale też krytycznie wypowiadało się o pracy służb miejskich. „Gazeta Narodowa” zwykle zamieszczała krótkie artykuły, często powołując się na publikacje „Kuriera”. Krytykowała Radę Miejską za wydawanie pieniędzy na różne „eksperymenty”, a nie przeznaczanie ich na walkę z chorobą, która

95 Wiadomości bieżące. Szkarlatyna, „Słowo Polskie” 1908, 366, s. 4; Wiadomości bieżace. Szkarlatyna we Lwowie, „Słowo Polskie” 1908, 368, s. 4.

96 S. Podolski, Autonomia, rząd i szkarlatyna, „Słowo Polskie” 1908, 397, s. 3; Zalewski, W kwestyji obecnej epidemii szkarlatyny, „Słowo Polskie” 1908, 402, s. 3; Epidemija szkarlatyny (Glos lekarza z prowincji), „Słowo Polskie” 1908, 408, s. 4; P. Kučera, Szkarlatyna, „Gazeta Narodowa" 1908, 207, s. 2.

97 Szkarlatyna, „Gazeta Narodowa” 1908, 197, s. 1.

98 Wykręty fizykackie, „Kurier Lwowski” 1908, 402, s. 2; Jak „,rząd thumi epidemje”, „Kurier Lwowski” 1908, 404, s. 2. 
„zabija setki dzieci”99. Stawiała tezę, że dopuszczenie do takiej epidemii jest „zbrodnią dokonaną na żywym organizmie narodu”, bo ludzie to ,jedyny nasz eksport” - ponieważ ,jesteśmy tak biedni”, a także ze względu na „zwiększenie się naporu niemieckiego z zachodu, naporu ukraińskiego ze wschodu i rosnącego po cichu w coraz większe rozmiary żydowstwa" (aluzje do polityki Cesarstwa Niemieckiego wobec Polaków, wzrost wpływu Ukraińców i Żydów w Galicji, w kontekście zabójstwa hrabiego Potockiego, walki sejmowej, a także aktywności radnych o pochodzeniu żydowskim w Lwowskiej Radzie Miejskiej, pozycji przedsiębiorców żydowskich w przemyśle naftowym itp.) ${ }^{100}$. Podobnie wypowiedział się także pewien lekarz w artykule opublikowanym w „Słowie”, nazywając epidemię jedną z najbardziej bolesnych ran „na ciele naszego narodowego organizmu", ponieważ choroby zakaźne zabierają więcej najlepszych jednostek niż wszystkie „pomysły naszych wrogów”101.

Lokalne czasopisma branżowe jak „Przegląd Higieniczny”, „Głos Lekarzy”, „Lwowski Tygodnik Lekarski” oraz „Przegląd Lekarski” podawały przeważnie krótkie wiadomości o epidemii. Kilka tekstów pojawiło się we „Lwowskim Tygodniku Lekarskim” ${ }^{02}$. Ukraiński dziennik polityczny „Dilo” w dyskusję nie wszedł w ogóle. Ukraińcy prawie nie posiadali przedstawicieli w Radzie Miejskiej i Magistracie oraz mieli mały wpływ na miejskie życie polityczne. Na przykład, kandydatura już wspomnianego lekarza Ozarkiewicza, którą wysuwano na wybory niejednokrotnie, nie uzyskała wystarczającej liczby głosów. Była to jedna z przyczyn braku szczególnego zainteresowania wydarzeniami życia miejskiego ze strony ludności ukraińskiej.

Prawdopodobnie istniał związek między dyskusją na temat szkarlatyny a niedawnymi wyborami do Rady Miejskiej. Przypomnijmy, że dwa komitety, które weszły do Rady, miały w swoim programie liczne propozycje reform w dziedzinie zdrowia publicznego oraz należeli do nich lekarze higieniści. Już od jakiegoś czasu trwały dyskusje o reformie miejskiej służby zdrowia, którą ciągle przekładano. Zaniedbania urzędu miejskiego stały się okazją do prób „ponaglenia” tej instytucji w sprawie realizacji reformy i innych działań. Skalę epidemii określono tuż po wyborach, kiedy emocje polityczne były jeszcze dość gorące. Najaktywniej analizował przebieg epidemii oraz wypominał błędy miejskiemu fizykatowi

\footnotetext{
99 Szkarlatyna, „Gazeta Narodowa” 1908, 198, s. 2-3.

100 Szkarlatyna, „Gazeta Narodowa” 1908, 197, s. 1.

101 Zalewski, W kwestyji obecnej epidemii szkarlatyny, „Słowo Polskie” 1908, 402, s. 3.

102 Różne wiadomości, „Lwowski Tygodnik Lekarski” 1908, 30, s. 398; 31, s. 352; J. Raczyński, W sprawie obecnej epidemii płonicy, „Lwowski Tygodnik Lekarski” 1908, 36,
} s. 407-408. 
i wiceprezydentowi Rutowskiemu w swoich artykułach Szczepan Mikołajski. Prawdopodobnie to on był autorem większej części publikacji na temat epidemii zamieszczonych w „Kurierze”, chociaż podpisał tylko kilka z nich. Zapewne oprócz rozbieżności politycznych, Mikołajski jako członek Komisji Zdrowotnej i higienista był niezadowolony z działalności wiceprezydenta i miejskiej służby zdrowia w ogóle. Gazety publikowały odpowiedzi Rutowskiego na wysunięte w prasie oskarżenia, a także jego zarzuty bezpodstawnego wywoływania paniki ${ }^{103} .1$ września $1908 \mathrm{r}$. miasto zaczęło wydawać biuletyn: „Korespondencję Ratuszową”, który informował o działalności Rady Miejskiej i Magistratu ${ }^{104}$. Dużo uwagi „Korespondencja” poświęcała szkarlatynie, publikowano dokładne dane statystyczne o liczbie nowych chorych i ich pochodzeniu (z dzielnicy miejskiej czy z powiatu), liczbie zmarłych, ozdrowieńców, leczonych i ogólnej liczbie chorych. Była to odpowiedź na krytykę fizykatu za brak danych o mieście i informowanie tylko o pojawieniu się choroby w gminach podmiejskich ${ }^{105}$. Dziennik ten przestał istnieć wiosną $1909 \mathrm{r}$.

Na posiedzeniu Rady Miejskiej 27 sierpnia 1908 r. na wniosek radnego Mikołajskiego została podjęta decyzja o stworzeniu komisji, która miała ustalić przyczyny wybuchu epidemii szkarlatyny, w szczególności niedociągnięć w pracy administracji miejskiej oraz zaproponować sposoby jej naprawy, żeby w przyszłości można było zapobiec podobnym sytuacjom ${ }^{106}$. Sprawozdanie pracy komisji, do której weszło 10 radnych, w tym wszyscy radni lekarze, zostało upublicznione w końcu czerwca 1909 r. W lipcu tego roku sprawozdanie opublikowano w kilku czasopismach („Dziennik Lwowski”, „Głos Lekarzy”, „Przegląd Higieniczny”), a także w oddzielnym wydaniu jako odbitkę z czasopisma branżowego.

${ }^{103}$ Czy jest we Lwowie epidemja?, „Kurier Lwowski” 1908, 379, s. 1-2. Artykuł jest niepodpisany, autorstwo Mikołajskiego wskazano w artykule: S. Mikołajski, Działalność lekarzy w Radzie miejskiej (1905-1911) i postęp sanitarny w mieście Lwowie, „Głos Lekarzy” 1911, 2, s. 17. Odpowiedź Rutowskiego, W sprawie epidemii szkarlatyny, „Kurier Lwowski” 1908, 380, s. 1. Niepodpisany artykuł Mikołajskiego Epidemja w pojęciu administracyjnem, „Kurier Lwowski” 1908, 387, s. 1-2; Szkarlatyna, „Gazeta Narodowa” 1908, 198, s. 2-3; Epidemia szkarlatyny w Galicji, „Kurier Lwowski” 1908, 408, s. 2-3; Z Rady miejskiej, „Słowo Polskie” 1908, 401, s. 1; Kto winien?, „Kurier Lwowski” 1908, 406, s. 1-2; Audiatur et altera pars. Z prezydyum miejskiego, „Słowo Polskie” 1908, 408, s. 3; Szkarlatyna. 32 ofiar dziennie, „Gazeta Narodowa” 1908, 200, s. 3; Usprawiedliwienie prezydium miasta, „Kurier Lwowski” 1908, 410, s. 2.

104 Zob. „Korespondencja Ratuszowa” 1908-1909 r., ЦДІА України у Львові, f. 146, op. 8a, sp. 202, 203, 204.

105 Zob. np. Przebieg epidemii szkarlatyny we Lwowie, „Kurier Lwowski” 1908, 394, s. 6-7.

${ }^{106}$ Rm. Posiedz. 27 sierpnia, „Dziennik Lwowski” 1908, 17, s. 359-360. 
Większa część dyskusji, zarówno w prasie, jak i na posiedzeniach struktur urzędniczych, sprowadzała się do sporu o granice pełnomocnictw i odpowiedzialności, w tym finansowej, różnych części systemu władz. Jedną z podstaw braku porozumienia między urzędem miejskim a Namiestnictwem były wydatki na lekarzy epidemicznych. Zgodnie z ustawą powinno ich zatrudnić państwo na swój koszt. Latem 1908 r. Namiestnictwo zobowiązało miasto do zatrudnienia siedmiu lekarzy epidemicznych. Jeszcze w listopadzie 1912 r. Magistrat lwowski przypominał Namiestnictwu o wypłacie funduszy na ich utrzymanie w latach 1908-1910 107 . Podobna sytuacja powtórzyła się też podczas epidemii szkarlatyny w 1912 i na początku 1913 r. Urząd miejski znów zwrócił się z prośbą o kompensację wydatków, a rozporządzenie o zwrocie miastu Lwów części wydatków podczas tej epidemii zostało wydane pod koniec października $1918 \mathrm{r}^{108}$

Miasto już od pewnego czasu było w sporze z władzami krajowymi z powodu leczenia zakaźnie chorych. We Lwowie nie było specjalnego szpitala. Oddziały dla takich chorych Szpitala Powszechnego Krajowego, podobnie jak szpitala dziecięcego św. Zofii zwykle były przepełnione. Te dwa szpitale obsługiwały i lwowian, i mieszkańców prowincji. Jak wyjaśniał Szczepan Mikołajski, w sporze z miastem w kwestii organizacji szpitala epidemicznego Wydział Krajowy powoływał się na określenie administracyjne epidemii (pięciu chorych) oraz zobowiązanie gminy do otwierania miejskich baraków epidemicznych, kiedy ta liczba zostaje przekroczona. Natomiast Magistrat podkreślał, że musi on stworzyć dodatkowe łóżka, kiedy w istniejących szpitalach zabraknie miejsc ${ }^{109}$.

Owa kwestia „szpitalna” niejednokrotnie powracała podczas dyskusji dotyczącej epidemii szkarlatyny w 1908 r. Szczególnie dyrektor szpitala św. Zofii, Jan Raczyński, widział główną przyczynę wybuchu epidemii w braku odpowiedniego szpitala. Uważał on, że obecnych 10 łóżek dla chorych na szkarlatynę w szpitalu św. Zofii nie wystarcza dla tak wielkiego miasta nawet w zwykłym okresie. $\mathrm{Z}$ braku miejsca nie było innego wyjścia jak kłaść dzieci na siennikach na podłodze. Oprócz tego, nie było udogodnień dla matek przebywających z dziećmi w szpitalu. Te czynniki,

107 List Magistratu m. Lwowa do c.k. Namiestnictwa, 23 XI 1912, ЦДІА України у Львові, f. 146, ор. 37, sp. 218, k. 36.

108 Rozporządzenie c.k. Namiestnictwa dla Krajowej Kasy Skarbowej, 28 X 1918, ЦДІА України у Львові, f. 146, op. 37, sp. 218, k. 65.

109 Spór miasta Lwowa $z$ Wydziałem krajowym w sprawie leczenia szpitalnego chorych zakaźnych, „Głos Lekarzy” 1906, 4, s. 5-6. Oddział zakaźny szpitala krajowego na 120 łóżek został otwarty w 1912 r., P. Franaszek, Zdrowie publiczne, s. 62. 
zdaniem lekarza, nie sprzyjały skuteczności leczenia, ani nie zachęcały rodziców do przyprowadzania dzieci do szpitala ${ }^{110}$.

Wokół opozycji miasto-prowincja rozwijała się dyskusja na temat pochodzenia epidemii. Istniało w tej kwestii kilka hipotez. Według pierwszej, szkarlatyna, jak i inne infekcje, ,przychodzą” do miasta z prowincji. Argument bazował na tym, że większość przypadków choroby pojawiało się najpierw w dzielnicach Żółkiewskiej i Gródeckiej (Krakowskiej), w których znajdowały się dworce oraz mieszkało dużo kolejarzy. Dlatego też należało najpierw poprawić stan sanitarny na prowincji, wtedy w wielkich miastach, szczególnie w Krakowie i Lwowie, nie byłoby ciągłych epidemii ${ }^{111}$. Istniała też opinia, że przyczyną rozpowszechnienia się choroby w tej części miasta był status socjalny jej mieszkańców i zaniedbania, którym winien był Magistrat, a które pozwalały tym dzielnicom konkurować z „najmniejszymi i najbrudniejszymi miasteczkami”"112. Inna teoria, wyrażana przez „Gazetę Narodową”, opierała się na argumencie wręcz przeciwnym - to Lwów jest źródłem choroby dla prowincji ${ }^{113}$. Jeszcze inne głosy w dyskusji wskazywały na potrzebę współpracy między miastem a władzą krajową w celu pokonania epidemii, ponieważ potrzeba poprawy stosunków zdrowotnych istniała i na prowincji, i we Lwowie. Zwolennicy ostatniego rozwiązania nie mieli wątpliwości co do tego, że w mieście są stałe ogniska choroby, które od czasu do czasu rozwijają się w większe lub mniejsze epidemie. Jednocześnie było wiadomo, że na szkarlatynę chorowano zarówno w bliższych, jak i odległych od miasta powiatach $^{114}$. To znaczy, że ani miasto nie jest winne wobec prowincji, ani odwrotnie.

Komisja stworzona w celu ustalenia przyczyn wybuchu epidemii szkarlatyny zaproponowała Radzie Miejskiej kilka rozwiązań, realizacja których, jej zdaniem, miałaby pomóc w walce z epidemiami w przyszłości. Reprezentacja miejska poprzez posłów sejmowych i parlamentarnych miałaby starać się o przyspieszenie uchwalenia ustawy o chorobach

110 J. Raczyński, W sprawie obecnej epidemii płonicy, „Lwowski Tygodnik Lekarski” 1908, 36, s. 407-408.

111 W. Legeżyński, Ruch ludności i choroby zakaźne w mieście Lwowie w r. 1908, 1909, 1910, „Głos Lekarzy” 1911, 10, s. 97-98; S. Podolski, Autonomia, rząd i szkarlatyna, „Słowo Polskie" 1908, 397, s. 1.

112 Zalewski, W kwestyji obecnej epidemii szkarlatyny, „Słowo Polskie” 1908, 402, s. 3.

113 Kronika Lwowska. Szkarlatyna, „Gazeta Narodowa” 1908, 196, s. 2; Szkarlatyna, „Gazeta Narodowa” 1908, 197, s. 1; Szkarlatyna. 32 ofiar dziennie, „Gazeta Narodowa” 1908, 201, s. 2; Kronika. Szkarlatyna we Lwowie, „Kurier Lwowski” 1908, 387, s. 3.

114 P. Kučera, Szkarlatyna, „Gazeta Narodowa” 1908, 207, s. 2; E. Piasecki, Epidemia płonicy, „Głos Lekarzy” 1909, 13, s. 151. 
zakaźnych, budowę specjalnego szpitala oraz organizację okręgów sanitarnych w powiatach, szczególnie tych sąsiadujących ze Lwowem. Komisja wezwała także do pracy nad przyłączeniem do Lwowa trzech gmin podmiejskich - Zamarstynowa, Zniesienia i Kleparowa, jak również jak najszybszego przystąpienia do regulacji dzielnicy III (Źółkiewskiej) i udoskonalenia systemu czyszczenia miasta ${ }^{115}$. Od fizykatu oczekiwano projektu reorganizacji miejskiej służby zdrowia i wprowadzenia systemu kontroli przez lekarzy dokładności przeprowadzanych dezynfekcji, rozwieszania kartek ostrzegawczych, zamykania pracowni i sklepów podczas następnych epidemii, a także stałej gotowości miejskich baraków epidemicznych ${ }^{116}$.

W podsumowaniu można stwierdzić, że współcześni wskazywali na rozmaite czynniki, które mogły przyczynić się do wybuchu epidemii. Uwagi dotyczyły istniejącej organizacji służby zdrowia publicznego: braku odrębnej ustawy o chorobach zakaźnych i ustawodawczego przymusu szpitalnego dla chorych, niewłaściwego podejścia administracji do pojęcia epidemii, podziału kosztów oraz obowiązków działań przeciwepidemicznych między państwem a gminą, niedostatecznej powiatowej opieki zdrowotnej i braku niezbędnej liczby miejsc w szpitalu dla chorych zakaźnie znajdujących się w mieście. Z mocną krytyką spotykała się działalność władz miejskich - nieregularność zwoływania Komisji Zdrowotnej oraz „nienależyte” traktowanie przez Radę Miejską i Magistrat spraw sanitarnych w ogóle, praca miejskiej służby zdrowia, brak starań w celu zapewnienia czystości i porządku w mieście, a także stan III dzielnicy i kwestia przyłączenia do miasta sąsiadujących z nią gmin.

\section{Epidemia: wyniki w liczbach}

W okresie od września 1907 r. do kwietnia 1910 r. według miejskich „Wiadomości Statystycznych” na szkarlatynę zachorowało 3617 osób, z czego 497 zmarło $^{117}$. Fizyk miejski Wiktor Legeżyński analizował epidemię w takich samych ramach czasowych, a statystykę zachorowalności oraz śmiertelności prowadził od października 1907 do marca 1910 r. Zgodnie z jego danymi zachorowało 3509 osób, z tego 3125 mieszkańców,

115 Nieco o czystości w mieście, V. Tracz, Higiena miasta. Kwestia zdrowia publicznego w polityce władz miejskich we Lwowie w końcu XIX i na początku XX wieku, w: Miasto w procesie przemian od czasów nowożytnych do współczesności, red. M. Gibiec, D. Wiśniewska, L. Ziątkowski, Kraków 2019, s. 205-227.

116 E. Piasecki, Epidemia płonicy, „Głos Lekarzy” 1909, 13, s. 188.

117 Wiadomości statystyczne o mieście Lwowie, Lwów 1910, 1911, 1914. 
pozostali to przyjezdni; łącznie zmarło 478 osób. Z tych, którzy zachorowali, 12 proc. stanowili dorośli, a pozostałą część dzieci, w tym 586 dzieci w wieku szkolnym ${ }^{118}$. Obliczenia na podstawie przedstawionych danych fizyka miejskiego wskazują, że ze wszystkich chorych 71 proc. (2501) stanowiły dzieci w wieku poniżej 6 lat.

Podczas epidemii trwały dyskusje o jej koncentracji w pewnych dzielnicach miasta, o czym była już mowa. Żeby lepiej zrozumieć te spory, warto krótko wspomnieć o cechach poszczególnych dzielnic miejskich. ówczesny architekt lwowski Ignacy Drexler dzielił Lwów na dwie części według wskaźników gęstości zabudowy i zaludnienia. Część południowo-wschodnia składała się z dzielnic Halickiej i Łyczakowskiej, zajmujących 62 proc. terenu miasta i będących terenami najbardziej „zielonymi”. Według jego obliczeń, w 1910 r. mieściło się tutaj 50 proc. domów i tylko 41 proc. ludności. W dzielnicy Żółkiewskiej w tym samym roku mieszkało 14,6 proc., w Śródmieściu - 6,4 proc., a na przedmieściu Krakowskim - 38,1 proc. mieszkańców. Dzielnice Krakowska i Żółkiewska były najgęściej zaludnione. Mieszkała tam największa część ludzi niezamożnych, wśród nich wielu Żydów ${ }^{119}$.

Tabela 1. Porównanie liczby mieszkańców, liczby zgonów oraz ich współzależność w dzielnicach Lwowa w $1910 \mathrm{r}$.

\begin{tabular}{|c|c|c|c|c|c|}
\hline Dzielnica & 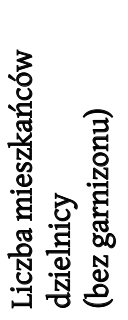 & 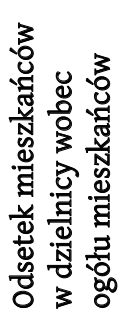 & 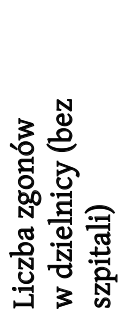 & 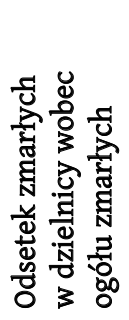 & 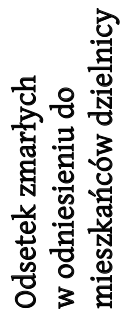 \\
\hline I (Halickie) & 51378 & 26,2 & 523 & 23,7 & 1,01 \\
\hline II (Krakowskie/Gródeckie) & 74611 & 38,1 & 878 & 39,8 & 1,8 \\
\hline III (Żółkiewskie) & 28501 & 14,6 & 348 & 15,8 & 1,2 \\
\hline IV (Eyczakowskie) & 28732 & 14,7 & 336 & 15,2 & 1,2 \\
\hline V (Śródmieście) & 12574 & 6,4 & 123 & 5,6 & 0,97 \\
\hline Razem & 195796 & & 2208 & & \\
\hline
\end{tabular}

Źródło: obliczenia własne na podstawie: liczba mieszkańców według dzielnic w 1910 r. zob. I. Drexler, Wielki Lwów, Lwów 1920, s. 48-50; liczba zgonów zob. Wiadomości statystyczne o mieście Lwowie, Lwów 1911, 1914.

118 W. Legeżyński, Ruch ludności, s. 109-110.

119 I. Drexler, Wielki Lwów, Lwów 1920, s. 20, 48-50. 
Tabela 2. Współzależność między liczbą zmarłych w dzielnicach miasta Lwowa w latach 1908-1909 r.

\begin{tabular}{|l|c|c|}
\hline \multicolumn{1}{|c|}{ Dzielnica } & $\begin{array}{c}\text { Liczba zgonów w dzielnicy } \\
\text { (bez szpitali) }\end{array}$ & $\begin{array}{c}\text { Odsetek zmarłych w dzielnicy } \\
\text { wobec ogółu zmarłych }\end{array}$ \\
\hline I (Halickie) & 1074 & 22,04 \\
\hline II (Krakowskie/Gródeckie) & 1775 & 36,4 \\
\hline III (Żółkiewskie) & 933 & 19,2 \\
\hline IV (Eyczakowskie) & 741 & 15,2 \\
\hline V (Śródmieście) & 348 & 7,1 \\
\hline Razem & 4871 & \\
\hline
\end{tabular}

Źródło: obliczenia własne na podstawie: Wiadomości statystyczne o mieście Lwowie, Lwów 1911, 1914.

Na podstawie analizy danych za 1910 r. widać, że procent zmarłych w dzielnicach w stosunku do ogółu zmarłych w mieście był proporcjonalny do procentu mieszkańców danej dzielnicy w stosunku do ogółu ludności Lwowa. Poziom umieralności w każdej dzielnicy w stosunku do liczby mieszkańców wahał się średnio w ramach 1,1 proc. Mniej niż 1 proc. wynosił on $\mathrm{w}$ Śródmieściu. W latach 1908-1909 procent umieralności w dzielnicach zbliżony był do wskaźników w roku 1910, chociaż zauważalny jest nieco wyższy wskaźnik w dzielnicach III i IV.

Rozpatrując statystykę podziału śmiertelności według dzielnic miasta podczas epidemii szkarlatyny za lata 1908-1909, widać, że zgodnie z danymi ujętymi w tabeli 3. najwięcej osób zmarło w II dzielnicy, dalej w I, III, IV i w Śródmieściu. Natomiast w odniesieniu do śmiertelności w obrębie każdej dzielnicy sytuacja wygląda nieco inaczej - najwyższe wskaźniki nadal są w II, dalej w IV, jednakowe wskaźniki mają dzielnice V i III, i najniższy - I.

Podział zachorowalności według dzielnic sanitarnych nie jest dokładny. Legeżyński wskazywał, że najwięcej ucierpiały „przeludnione okręgi" - tzw. Gródeckie (44 proc.) i Żólkiewskie (17 proc.), dalej Łyczaków (16 proc.), Śródmieście (8 proc.), Zielone (8 proc.), Chorąszczyzna (7 proc. $)^{120}$. Przypuszczamy, że podaje on dane w odniesieniu do liczby chorych lwowian - czyli 3125 osób. Dzielnica sanitarna „Żólkiewskie” oraz dzielnica sanitarna „Śródmieście” mniej więcej pokrywają się z dzielnicami administracyjnymi III i V. Jeżeli dokonać obliczeń, to w III dzielnicy zachorowały 554 osoby, a w V - 256, co w odniesieniu do ludności owych dzielnic administracyjnych w 1910 r. wynosi odpowiednio 1,9 proc. i 2,03 proc. Wspomniana dzielnica sanitarna „Gródeckie” było częścią II dzielnicy administracyjnej.

120 W. Legeżyński, Ruch ludności, s. 109-110. 
Tabela 3. Śmiertelność z powodu szkarlatyny w dzielnicach administracyjnych (bez szpitali) w latach 1908-1909

\begin{tabular}{|l|c|c|c|c|c|}
\hline & \multicolumn{5}{|c|}{ Liczba zgonów } \\
\cline { 2 - 6 } & $\begin{array}{c}\text { I } \\
\text { dzielnica }\end{array}$ & $\begin{array}{c}\text { II } \\
\text { dzielnica }\end{array}$ & $\begin{array}{c}\text { III } \\
\text { dzielnica }\end{array}$ & $\begin{array}{c}\text { IV } \\
\text { dzielnica }\end{array}$ & $\begin{array}{c}\text { V } \\
\text { dzielnica }\end{array}$ \\
\hline 1908 & 26 & 67 & 28 & 20 & 7 \\
\hline 1909 & 20 & 44 & 15 & 18 & 9 \\
\hline $\begin{array}{l}\text { Liczba zgonów z powodu } \\
\text { szkarlatyny w ciągu dwóch lat } \\
\text { w dzielnicach }\end{array}$ & 46 & 111 & 43 & 38 & 16 \\
\hline $\begin{array}{l}\text { Odsetek zmarłych z powodu } \\
\text { szkarlatyny według kryterium } \\
\text { wszystkich zmarłych } \\
\text { w dzielnicach 1908-1909 }\end{array}$ & 4,3 & 6,3 & 4,6 & 5,1 & 4,6 \\
\hline
\end{tabular}

Źródło: obliczenia własne na podstawie: Wiadomości statystyczne o mieście Lwowie, Lwów 1911.

W sprawozdaniu o epidemii dwukrotnie wspomniane było samo przedmieście Żółkiewskie (III) - najpierw jako źródło pojawienia się epidemii w mieście, a później poprawę sytuacji („uzdrowotnienie”) w tej dzielnicy wymieniano na pierwszym miejscu wśród zaleceń, których udzieliła komisja po analizie przebiegu epidemii szkarlatyny. $\mathrm{Na}$ podstawie przedstawionych obliczeń możemy przypuścić, że częściowo takie skupienie uwagi tylko na dzielnicy Żółkiewskiej podczas tej epidemii nie było uzasadnione. Większej uwagi „sanitarnej” potrzebowała także i reszta dzielnic, szczególnie Śródmieście i przedmieście Krakowskie, chociaż podczas następnej epidemii szkarlatyny w 1912 r. choroba początkowo koncentrowała się tylko w Żółkiewskiej ${ }^{121}$. Jak donosił fizykat miejski, istniał problem z oddawaniem dzieci z rodzin żydowskich do szpitala epidemicznego dlatego, że nie posiadał on kuchni rytualnej ${ }^{122}$.

Zdaniem współczesnych, dzielnica III często występowała jako źródło wszystkich możliwych epidemii oraz rozsadnik zaraz. Heidi Hein-Kircher wskazuje, że opinie te uwarunkowane były antysemityzmem ${ }^{123}$. Sposobów na rozwiązanie problemów dzielnicy Żółkiewskiej poszukiwano przez długie lata. W 1891 r. Rada Miejska postanowiła przebudować 181 domów ze względów „asenizacyjnych” oraz regulacyjnych. Część z nich znajdowała się w dzielnicy III ${ }^{124}$. W latach 1909-1910 przygotowano odrębny

${ }^{121}$ Kronika. Płonica we Lwowie, „Kurier Lwowski” 1912, 305, s. 4.

${ }^{122}$ Kronika. Posiedzenie miejskiej komisji zdrowotnej, „Kurier Lwowski” 1912, 393, s. 3-4.

${ }^{123}$ H. Hein-Kircher, op. cit., s. 141-143.

124 Miasto Lwów w okresie samorzadu, s. 349-350. 
plan regulacji dla Żółkiewskiego ${ }^{125}$. W lutym 1913 r. kolejny raz lekarze higieniści pisali, że plan ten „trzeba konsekwentnie przeprowadzić"126. W tej części miasta funkcjonowały targowiska bydlęce, drzewne, waga miejska, dworzec kolejowy, rzeźnie miejskie i inne „brudne” przedsiębiorstwa gospodarki miejskiej. Na teren położony blisko granic dzielnicy wywożono zawartość dołów kloacznych ${ }^{127}$. W $1911 \mathrm{r}$. autor „ze sfer lekarskich” w czasopiśmie proasymilacyjnym pisał, „w samym centrum miasta mamy «Mało-azjatyckie» stosunki sanitarne” i „nieraz już skarżyliśmy się na stosunki w dzielnicach żydowskich, nieraz wołaliśmy, iż już czas najwyższy poważnie zająć się asanacyą tych dzielnic miasta. $\mathrm{Na}$ razie wszystko daremnie!"128. Mówiono też o zaniedbaniu części dzielnicy II, która z Żołkiewską stanowiła „dzielnice żydowskie”. Dane statystyczne z badanej epidemii szkarlatyny dają podstawy przypuszczać, że takie etykietowanie tej część miasta jako źródła wszystkich zaraz nie zawsze było uzasadnione. Oczywiście kwestia rozwoju dzielnicy III wymaga oddzielnego badania w kontekście problemu antysemityzmu.

\section{Podsumowanie}

Epidemia szkarlatyny w latach 1907-1910 we Lwowie miała kilka cech specyficznych. Chociaż była największą epidemią tej choroby w okresie od końca XIX do początku XX w., przez długi czas wydawała się prawie niezauważalna dla urzędu miejskiego, po czym na kilka miesięcy stała się jednym z centralnych wydarzeń życia miejskiego, które omawiano w prasie codziennej. Ważnym czynnikiem, mającym wpływ na taką sytuację, związanym zarówno z działaniami przeciwepidemicznymi, jak i z późniejszą dyskusją prasową, były wybory do Sejmu Galicyjskiego, a zwłaszcza do Lwowskiej Rady Miejskiej w pierwszym półroczu 1908 r. Wywarły one dwojaki wpływ na pracę Rady Miejskiej i Komisji Zdrowotnej w szczególności. Z jednej strony, naruszyły zwykły tryb działania urzędów. Członkowie Komisji, analizując przyczyny pojawienia się epidemii przypuszczali, że regularne zwoływanie jej posiedzeń mogłoby pomóc nadrobić zaniedbania fizyka miejskiego. $Z$ drugiej zaś strony, prawdopodobnie również związane z wyborami, było rozpoczęcie latem 1908 r. dyskusji z inicjatywy oraz przy udziale lekarzy higienistów. Zainteresowanie

\footnotetext{
125 Rada miejska, „Dziennik Lwowski” 1909, 11, s. 259-260; 1910, 11, s. 249-250.

${ }^{126}$ Higiena społeczna $w$ gospodarce m. Lwowa, „Głos Lekarzy” 1913, 3, s. 26.

127 П. Гранкін, op. cit., s. 64.

128 Pod adresem Rady miejskiej, „Jedność” 1911, 37, s. 4-5.
} 
ze strony prasy zmusiło urząd miejski do większej aktywności w walce $\mathrm{z}$ epidemią. Polemika toczyła się właśnie $\mathrm{w}$ dziennikach, a nie czasopismach branżowych, co czyniło ją dostępną dla szerokiej publiczności, a nie tylko fachowców. Krytyka zmuszała wiceprezydenta miasta do pisania odpowiedzi oraz wyjaśnień, a także rozliczania się z pracy fizykatu w specjalnym biuletynie „Korespondencja Ratuszowa”. Dzięki propozycji najbardziej aktywnego lekarza higienisty w Radzie Miejskiej tego czasu, Szczepana Mikołajskiego, została powołana komisja do ustalenia przyczyn wybuchu epidemii o takiej skali. Jej pracę zwieńczyło sprawozdanie, które zawierało analizę przebiegu epidemii, możliwe przyczyny jej pojawienia się oraz zalecenia dla Rady Miejskiej w celu zapobiegania podobnym sytuacjom w przyszłości.

Reakcja urzędu miejskiego na epidemię świadczyła o poważnych problemach i usterkach w pracy miejskiej służby zdrowia. Oczywiście, część $\mathrm{z}$ nich była wynikiem istniejącego systemu ochrony zdrowia w ogóle. Jednocześnie nierozwaga fizyka oraz prezydenta miasta, którzy nie dopełnili obowiązków służbowych, brak posiedzeń Komisji Zdrowotnej wskutek wyborów pozwala postawić kilka hipotez. Zapewne dochodziło do przypadków niesumienności urzędników miejskich. Kwestie zdrowia publicznego widocznie nie były priorytetem dla urzędu miejskiego, a zagadnienia polityczne miały przewage nad codziennymi sprawami miejskimi. Lwów jako stolica prowincji znajdował się w centrum „wielkiej” polityki krajowej. Jednocześnie samorząd miejski miał dbać o zaspokojenie potrzeb gminy. Połączenie tych kwestii stało się wyzwaniem dla Lwowa, szczególnie na początku XX w. wraz z zaognieniem konfliktów polityczno-narodowych. Ogólnokrajowe sprawy polityczne wypierały z programu codziennego Rady Miejskiej pilne potrzeby lokalne. Radni jednocześnie wskazywali, że Lwów jako stolica prowincji ma odpowiadać swojemu statusowi we wszystkich dziedzinach, w tym w sprawach sanitarnych.

W przypadku epidemii szkarlatyny pewne znaczenie ma także postrzeganie samej choroby. Jako zagrożenie rozumieli ją lekarze higieniści, którzy alarmowali, wskazując na wysoką śmiertelność dzieci w wieku poniżej 5 lat. Natomiast urzędnicy i reszta społeczeństwa podchodzili do tych danych dość spokojnie, sądząc po ich zachowaniu podczas epidemii. Oczywiście infekcje szkarlatyny dotyczyły prawie wyłącznie dzieci i na początku XX w. były już mniej śmiertelne, np. w porównaniu do cholery, ospy prawdziwej lub duru brzusznego, zarażających wszystkich i odznaczających się wysoką śmiertelnością. Ponadto istniała jeszcze strona finansowa walki z epidemią, dotycząca zarówno budżetu miejskiego, jak i samych mieszkańców. Działania przeciwepidemiczne 
pociągały za sobą dodatkowe wydatki dla miasta, których część miało ponieść państwo, jednak jeszcze przez lata władze miejskie oczekiwały od krajowych zwrotu kosztów. Urząd miejski próbował wydzielać pieniądze na pomoc tylko najbiedniejszym rodzinom. Pozostali mieszkańcy, spełniając wymogi izolacji, ponosili straty ekonomiczne.

Dyskusja, którą rozpoczął na łamach „Kuriera Lwowskiego” Mikołajski, miała na celu nie tylko zwrócenie uwagi na konkretny problem epidemię szkarlatyny, lecz także ogólnie na kwestię polityki urzędu miejskiego w zakresie zdrowia publicznego. Niedawne wybory i „niezauważona" epidemia były dobrą do tego podstawą. Podczas debat, w których brało udział kilku innych lekarzy, omawiano problemy zdrowia publicznego nie tylko we Lwowie, lecz także w całym kraju oraz ich ścisłe wzajemne powiązania. Analizując sytuację w mieście w publikacjach prasowych, a także w sprawozdaniu komisji badającej przyczyny powstania epidemii, autorzy powtarzali główne żądania z programów przedwyborczych dwóch komitetów, przedstawiciele których, zwłaszcza lekarze higieniści, trafili do nowej Rady Miejskiej. Niektóre z tych postulatów, szczególnie ten dotyczący regulacji dzielnicy Żółkiewskiej, niejednokrotnie pojawiały się także i po 1908 r. Przeprowadzona analiza danych statystycznych, zebranych przez fizykat miejski, nie potwierdza opinii o III dzielnicy jako głównym ognisku zarazy w czasie tej epidemii. Jednak nie zaprzecza faktu „sanitarnego” zaniedbania tej części miasta. Badania szczegółów polityki miejskiej w kwestii uporządkowania i rozwoju różnych dzielnic miasta, zwłaszcza pod kątem higieny miejskiej, wymagają kontynuacji. Lekarze higieniści, którzy byli radnymi miejskimi, wykorzystywali swoją pozycję oraz wiedzę ekspercką w celu wpływania na politykę samorządu. Miejscowi higieniści nie tylko próbowali szerzyć wiedzę z zakresu higieny, lecz także sprzyjać jej wprowadzeniu w miejskiej przestrzeni Lwowa.

\section{Streszczenie}

Na koniec XIX - początek XX w. przypada okres przełomowy w historii przemiany Lwowa w nowoczesną metropolię. Ważnym elementem tego procesu było nadanie prawa samorządu w 1870 r. Rozwój miasta wymagał rozbudowy infrastruktury miejskiej oraz służb miejskich. Liczne zmiany zostały również podyktowane przez idee zdrowia publicznego. Te wszystkie czynniki zmuszały urząd miejski do większej dbałości o zdrowie publiczne, w tym zorganizowania miejskiej służby zdrowia. Działalność na tym polu była przedmiotem dumy urzędników. Jednak uwagi krytyczne stale pojawiały się w środowisku higienistów. Epidemie chorób zakaźnych były próbą skuteczności pracy służby zdrowia. Badana epidemia miała kilka cech 
charakterystycznych - była największą epidemią szkarlatyny w omawianym okresie, przez długi czas pozostawała niezauważana przez władze miejskie i wywołała burzliwą dyskusję prasową. Ważnym czynnikiem, związanym zarówno z działaniami przeciwepidemicznymi, jak i późniejszą dyskusją prasową, były wybory do Sejmu Galicyjskiego, a także do Lwowskiej Rady Miejskiej w pierwszym półroczu 1908 r., w których uczestniczyli także lekarze higieniści. Dyskusja rozpoczęła się latem 1908 r. z inicjatywy oraz z udziałem higienistów. Istnieją podstawy, aby uważać, że to presja prasy zmusiła urząd miejski do większej aktywności w walce z epidemią. Omawiano wtedy problemy zdrowia publicznego nie tylko we Lwowie, lecz także w kraju oraz ich ścisłe wzajemne powiązania. Higieniści, którzy byli radnymi miejskimi, wykorzystywali swoją pozycję oraz wiedzę ekspercką w celu wpłynięcia na miejską politykę w tej kwestii. Poprzez rozgłos i krytykę publiczną administracja miejska była zmuszona do udzielenia wyjaśnień. Reakcja urzędu miejskiego na epidemię świadczyła o poważnych problemach i usterkach w pracach miejskiej służby zdrowia.

\section{The Scarlet Fever epidemic in Lviv, 1907-10. City Authorities, Hygienists, and Public Health Policy}

At the turn of the twentieth century, Lviv had been transformed into a modern city. An essential factor in this process was the granting of the right to municipal government in 1870. The city's growth required the expansion of the urban infrastructure and municipal services. New ideas of public health also dictated numerous changes. All these factors forced the city council to take care of the health in the city, including the organisation of the municipal health service. Activities in the field of public health were the pride of the city council. However, the hygienist community constantly voiced critical comments. Outbreaks of infectious diseases tested the effectiveness of this health service. The scarlet fever epidemic of 1907-1910 had several peculiarities: it was Lviv's largest scarlet epidemic of the late nineteenth and early twentieth century; for a long time, it was 'unnoticed' by the municipal authorities, and it gave rise to a particularly interesting press discussion. A crucial and unique factor related to both the anti-epidemic activities and the subsequent press discussion were the elections to the Galician Diet and the Lviv City Council in the first half of 1908. Many medically-qualified hygienists participated in this public debate. The discussion began in the summer of 1908 on the initiative and with the participation of hygienists. There are grounds to believe that the press discussion forced the city council to be more active in the fight against the epidemic. At that time, public health problems in Lviv and the whole province of Galicia and their close interrelatedness were widely discussed. Hygienists who were city councillors (i.e., city council deputies) used their position and expertise to change city public health policy. Due to public criticism, the city administration sought to provide the population with some explanations. The municipal office's reaction to the epidemic proved the severity of problems and failures in the public health policy. 


\section{Bibliografia}

\section{Edycje źródłowe}

Baranowski Mieczysław, Hygiena przystępnie wyłożona, red. Józef Szpilman, Staranniem „Towarzystwa przyjaciół zdrowia”, nakładem księgarni Pawła Starzyka, Lwów 1891.

Legeżyński Wiktor, Ruch ludności i choroby zakaźne w mieście Lwowie w r. 1908, 1909, 1910, „Głos Lekarzy” 1911, 10, s. 109-110.

Legeżyński Wiktor, Stosunki zdrowotne w mieście Lwowie w roku 1905 i 1906, Nakładem gminy król. stoł. miasta Lwowa, Drukiem W.A. Szyjkowskiego, Lwów 1907.

Miasto Lwów w okresie samorządu, 1870-1895, Nakładem gminy król. stoł. miasta Lwowa, Z drukarni W.A. Szyjkowskiego, Lwów 1896.

Pawlikowski Antoni, o stosunkach zdrowotnych w mieście Lwowie, Nakładem król. stoł. miasta Lwowa, Z drukarni W.A. Szyjkowskiego, t. 1 (sprawozdanie za r. 1888), Lwów 1891, t. 2 (sprawozdanie za lata od 1889 do 1893), Lwów 1894.

Podręcznik statystyki Galicyi, wyd. przez Krajowe Biuro Statystyczne, Z pierwszej związkowej drukarni we Lwowie, Lwów 1900, t. 6, cz. 1; 1903, t. 7, cz. 1; 1908, t. 8, cz. 1; 1913, t. 9, cz. 1.

Rocznik statystyki Galicyi, wyd. przez Krajowe Biuro Statystyczne, Z drukarni i litografii Pillera i spółki, Lwów 1887, 1889, 1891, 1893, 1898, r. 1-5.

Sprawozdanie klubu radnych (centrum) z czynności w Radzie miasta Lwowa za trzechlecie 1905-1908, Drukarnia udziałowa, Lwów 1908.

Ustawa karna $z$ dnia 27 maja 1852. Część druga. O występkach i przekroczeniach, oprac. Józef Sułkowski, Nakładem księgarni Leona Frommera, Drukarnia Uniwersytetu Jagiellońskiego, Kraków 1906.

Wiadomości statystyczne o mieście Lwowie, Nakładem gminy miasta Lwowa, Z drukarni narodowej W. Manieckiego, Lwów 1874, 1; 1876, 2; 1877, 3.

Wiadomości statystyczne o mieście Lwowie, Nakładem gminy król. stoł. miasta Lwowa, Z drukarni W.A. Szyjkowskiego, Lwów 1892, 1; 1893, 2; 1895, 6; 1897, 7; 1905, z. 10, cz. 1; 1907, z. 11, cz. 1; 1910, 12; 1911, 13; 1914, 14; 1926, 15.

Zbiór ustaw i rozporządzeń administracyjnych w Królewstwie Galicyi i Lodomeryi z Wielkiem Księstwem Krakowskim obowiazujących z wyciagiem orzeczeń c.k. Trybunału administracyjnego. Podręcznik dla organów c.k. Władz rządowych $i$ władz autonomicznych, ułożył i wyd. Jan Rudolf Kasparek, Nakładem Wydawcy, t. 3, Lwów 1885.

Zbiór ustaw i rozporządzeń sanitarnych ze szczególnem uwzględnieniem Galicji i W. Księstwa Krakowskiego, zest. Józef Barzycki, Zdzisław Lachowicz, Leon Kruszyński, Własnym nakładem, z drukarni i litografii Pillera i Spł., t. 2, Lwów 1899.

Озаркевич Євген, Порадник гігієнічно-лікарський. Недуги пошестні, з друкарні Наукового Товариства ім. Шевченка, Львів 1911. 


\section{Opracowania}

Architektura Lwowa XIX wieku, red. Jacek Purchla, Międzynarodowe Centrum Kultury, Kraków 1997.

Berner Włodzimierz, Stan sanitarny, ochrona zdrowia i sytuacja epidemiologiczna chorób zakaźnych we Lwowie w okresie autonomii Galicyjskiej (lata 60./70. XIX w. - do 1914 r.), „Przegląd Epidemiologiczny” 61, 2007, 4, s. 815-825.

Binder Harald, Making and Defending a Polish Town. „Lwów” (Lemberg) 1848-1914, „Austrian History Yearbook" 2003, 34, s. 57-81.

Brzozowski Stanisław M., Piasecki Eugeniusz Witold, http://www.ipsb.nina.gov.pl/a/ biografia/eugeniusz-witold-piasecki (dostęp: 5 III 2021).

Brzozowski Stanisław M., Piasecki Eugeniusz Witold, PSB, t. 25, Wrocław-WarszawaKraków 1980, s. 774-777.

Demel Maciej, Pedagogiczne aspekty warszawskiego ruchu higienicznego (1864-1914), Ossolineum, Wrocław 1964 (Monografie Pedagogiczne, t. 12).

Dolata Elżbieta, Rozwój ruchu higienicznego w Galicji w okresie autonomicznym ze szczególnym uwzględnieniem higieny szkolnej, Wydawnictwo Uniwersytetu Rzeszowskiego, Rzeszów 2016 (Galicja i jej dziedzictwo, t. 23).

Drexler Ignacy, Wielki Lwów, Nakładem Gminy Miasta Lwowa, Drukarnia W.A. Szyjkowskiego, Lwów 1920.

Franaszek Piotr, Informator statystyczny do dziejów społeczno-gospodarczych Galicji. Zdrowie publiczne $w$ Galicji $w$ dobie autonomii, red. Helena Madurowicz-Urbańska, Historia Iagellonica, Kraków 2001 (Informatory Statystyczne do Dziejów Społeczno-Gospodarczych Galicji, t. 15).

Franaszek Piotr, Publiczna ochrona zdrowia $w$ Galicji $w$ dobie autonomii, w: Przełom nowożytny $w$ nauce europejskiej i jego kontekst społeczno-kulturowy, red. Bożena Płonka-Syroka, Andrzej Syroka, Arboretum, Wrocław 2004 (Studia z Dziejów Kultury Medycznej, t. 8), s. 133-157.

Franaszek Piotr, Zdrowie publiczne $w$ Galicji w dobie autonomii (wybrane problemy), Wydawnictwo UJ, Kraków 2002.

Hardy Anne, The Epidemics Streets. Infectious Disease and the Rise of Preventive Medicine. 1856-1900, Oxford University Press, New York 1993.

Hein-Kircher Heidi, Best Practices From a Polish Perspective. Improving Health Conditions in Lviv Around 1900, w: Interurban Knowledge Exchange in Southern and Eastern Europe, 1870-1950, red. Eszter Gantner, Heidi Hein-Kircher, Oliver Hochadel, Routledge, New York 2021 (Routlege advances in urban history, t. 9), s. 134-152.

Hietala Marjatta, Services and Urbanization at the Turn of the Century. The Diffusion of Innovations, Societas Historica Finlandiae, Helsinki 1983.

Hoszowski Stanisław, Ceny we Lwowie w latach 1701-1914, Kasa im. Rektora J. Mianowskiego, Instytut Popierania Polskiej Twórczości Naukowej, Lwów-Warszawa 1934 (Badania z Dziejów Społecznych i Gospodarczych, nr 13).

Hoszowski Stanisław, Ekonomiczny rozwój Lwowa w latach 1772-1914, Wydawnictwo Izby Przemysłowo-Handlowej, Lwów 1935.

Jastrzębowski Zbigniew, Spory o model lecznictwa. Opieka zdrowotna w koncepcjach polskiej polityki społecznej w XIX i XX wieku (do 1948 roku), Akademia Medyczna, Łódź 1994. 
Katz Alan R., Morens David M., Severe Streptococcal Infections in Historical Perspective, „Clinical Infectious Diseases” 14, 1992, 1, s. 298-307.

La Berge Ann F., Mission and Method. The Early Nineteenth-Century French Public Health Movement, Cambridge University Press, Cambridge, New York 1992.

Lewicki Jakub, Między tradycją a nowoczesnościa. Architektura Lwowa lat 1893-1918, Neriton, Warszawa 2005.

Łupienko Aleksander, Rivers, Public Hygiene and Urban Feelings. The Case of the Pettew River in Lviv before 1914, „Biuletyn Polskiej Misji Historycznej” 14, 2019, s. 363-382.

Łupienko Aleksander, Some Remarks on the Birth of Modern City Planning in the Polish Territories (1850-1914). The Impact of the Hygienic Movement, „Mesto a dejiny” 5, 2016, 2, s. 18-34.

Łupienko Aleksander, Transnational Modernization of the Periphery? The Role of Engineers in the Rise of Modern Lviv (1870-1914), „Yearbook of Transnational History” 3, 2020, s. 55-74.

Łupienko Aleksander, Urban Knowledge Transfer Between the Cities of Warsaw, Krakow, Lviv and Poznan at the Turn of the Nineteenth and Twentieth Centuries, „Zeitschrift für Ostmitteleuropa-Forschung" 67, 2018, 4, s. 578-600.

Łupienko Aleksander, Wkład ruchu higienicznego w polską myśl urbanistyczna (1850-1914), w: Architektura w mieście, architektura dla miasta. Społeczne aspekty funkcjonowania architektury na ziemiach polskich lat 1815-1914, red. Mikołaj Getka-Kenig, Aleksander Łupienko, Instytut Historii PAN, Warszawa 2017, s. 57-70.

Małecki Jan M., „Mieszkaja w prawdziwym raju” (Możliwości badania jakości życia $w$ Krakowie $i$ we Lwowie $w$ okresie autonomii galicyjskiej), „Annales Universitatis Paedagogicae Cracoviensis. Studia ad Bibliothecarum Scientiam Pertinentia" 9, 2011, s. 157-164.

Ogórek Bartosz, Niezatarte piętno? Wpływ I wojny światowej na ludność Krakowa, Universitas, Kraków 2018.

Pilch Andrzej, Mikołajski Szczepan Jan, PSB, t. 21, Wrocław 1976, s. 156-157.

Prokopovych Markian, Habsburg Lemberg. Architecture, Public Space, and Politics in the Galician Capital, 1772-1914, Purdue University Press, West Lafayette 2008.

Rejman Sabina, Organizacja państwowej i gminnej służby zdrowia w Galicji w okresie autonomicznym $w$ świetle przepisów prawnych, w: Urzędy państwowe, organy samorządowe $i$ kościelne oraz ich kancelarie na polsko-ruskim pograniczu kulturowym i etnicznym w okresie od XV do XIX wieku, red. Henryk Gmiterek, Janusz Łosowski, Avalon, Kraków 2010, s. 405-435.

Rosen George, A History of Public Health, Johns Hopkins University Press, Baltimore 2015.

Sroka Łukasz Tomasz, Rada miejska we Lwowie w okresie autonomii galicyjskiej 1870-1914. Studium o elicie władzy, Wydawnictwo Naukowe Uniwersytetu Pedagogicznego, Kraków 2012.

Sroka Stanisław Tadeusz, Szpilman Józef Baltazar, PSB, t. 48, Warszawa-Kraków 2012-2013, s. 635-637.

Swedlund Alan C., Donta Alison K., Scarlet Fever Epidemics of the Nineteenth Century. A Case of Evolved Pathogenic Virulence?, w: Human Biologists in the Archives. Demography, Health, Nutrition and Genetics in Historical Populations, red. D. Ann Herring, 
Alan C. Swedlund, Cambridge University Press, Cambridge, New York 2003, s. $159-177$.

Tomczyk Ryszard, Zagrożenia epidemiologiczne na terenie austriackiej części monarchii habsburskiej w XIX w. (do 1914 r.). Aspekty prawne i administracyjne, „Galicja. Studia i Materiały" 2015, 1, s. 99-113.

Tracz Vira, Higiena miasta. Kwestia zdrowia publicznego $w$ polityce władz miejskich we Lwowie w końcu XIX i na początku XX wieku, w: Miasto $w$ procesie przemian od czasów nowożytnych do współczesności, red. Magdalena Gibiec, Dorota Wiśniewska, Leszek Ziątkowski, Księgarnia Akademicka, Kraków 2019, s. 205-227.

Willcox Walter F., Statistics at International Congresses on Hygiene and Demography, „Publications of the American Statistical Association” 13, 1912, 98, s. $182-185$.

Wnęk Konrad, Nierówność społeczna wobec śmierci we Lwowie w końcu XIX i na poczatku XX wieku, w: Choroba i śmierć w perspektywie społecznej w XIII-XXI wieku, red. Dariusz K. Chojecki, Edward Włodarczyk, DIG, Warszawa 2010, s. 221-250.

Wnęk Konrad, Przemiany demograficzne we Lwowie w latach 1829-1938, „Zeszyty Naukowe UJ. Prace Historyczne" 135, 2008, s. 113-127.

Wnęk Konrad, Zyblikiewicz Lidia A., Callahan Ewa, Ludność nowoczesnego Lwowa w latach 1857-1938, Towarzystwo Naukowe Societas Vistulana, Kraków 2006.

Zayarnyuk Andriy, Lviv's Uncertain Destination. A City and Its Train Terminal from Franz Joseph I to Brezhnev, University of Toronto Press, Toronto-Buffalo 2020.

Гранкін Павло, Каналізація міста Львова (від початку XV cm. до 1939 р.), Аверс, Львів 2015.

Долинська Мар'яна, Украӥнські квартали в часі австрійського періоду Львова, „Вісник Державного університету «Львівська політехніка»” 1999, 379, s. 199-204.

Жук Ігор, Львів Левинського. Місто і будівничий, Грані-Т, Київ 2010.

Кіселичник Василь, Міське право та самоврядування громади Львова (друга половина ХІХ - початок ХХ сm.), ЛьвДУВС „Край”, Львів 2008.

Середа Остап, Щоденне життя, w: Історія Львова, t. 2: 1772-1918, red. Ярослав Ісаєвич, Микола Литвин, Феодосій Стеблій, Центр Європи, Львів 2007, s. 318-333.

Трач Віра, „Гігієна є мірилом культури”. Украӥнські фахові кола та гігієнічний рух у Львові на початку XX cm., „Україна. Культурна спадщина, національна свідомість, державність" 2019, 32, s. 22-44.

Трач Віра, „Для культури в напрямку гігієни”. Громадське здоров'я та „виставковий комплекс” у Львові наприкінизі ХІХ - на початку XX сm., „Місто. Історія, культура, суспільство" 2019, 1, s. 99-118.

Трач Віра, „Живемо під знаком гігієни”. Професійні з"їзди другої половини ХІХ початку XX cm. та розвиток гігієнічного руху в Галичині, „Дослідження з історії і філософії науки і техніки" 2019, 2, s. 20-41.

Трач Віра, Гігієнічні часописи та формування дискурсу громадського здоров'я у Львові на початку XX столітmя, „Місто. Історія, культура, суспільство” 2017, 2, s. 136-161. 
Трач Віра, Органи „громадської служби здоров'я” в структурі Львівського магістрату наприкінц̧і XIX - на початку XX cm., „Проблеми історії України XIX - поч. ХX ст." 28, 2018, s. 125-140.

Харчук Христина, Водогін міста Львова, (від початку XV cm. до 1939 р.), Аверс, Львів 2015.

Biogram: Vira Tracz - doktorantka wydziału Humanistycznego Ukraińskiego Uniwersytetu Katolickiego. Zainteresowania naukowe - historia ruchu higienicznego, modernizacja miast w Galicji od połowy XIX w. do 1914 r. z punktu widzenia koncepcji zdrowia publicznego; kontakt: viratracz@ucu.edu.ua.

Author: Vira Tracz - PhD student at the Humanities Faculty of the Ukrainian Catholic University. Research interests: history of the hygiene movement, modernisation of cities in Galicia between 1850 and 1914 through the prism of the public health; contact: viratracz@ucu.edu.ua. 